УДК $330.342+330.11$

ББК 65.011

\title{
ЭКОНОМИКА РИСКОВ
}

\author{
С. Ю. СОЛОДОВНИКОВ \\ solodovnicov_s@tut.by
}

доктор экономических наук, профессор, заведующий кафедрой «Экономика и право» Белорусский национальный технический университет

г. Минск, Республика Беларусь

Статья посвящена теоретическому обоснованию новой соииальной парадигмь экономике рисков. Современный этап развития общества и экономики характеризуется критическим нарастанием финансовых, технико-технологических, политико-экономических, геоэкономических и других неопределенностей. Понять их онтологическую природу и раскрыть феноменологическую специфику нельзя без содержательного определения нынешней стадии развития экономической системы общества. В статье последовательно раскрыты характеристики современного общества, что позволило автору представить новый политико-экономический концепт, характеризующий современный этап развития общества и экономики, - экономику рисков. Экономика рисков это экономика высокотехнических и наукоемких производств, характеризующаяся высочайшей степенью политико-экономических, технологических, финансовых и экологических неопределенностей и рисков. Эти риски принимают всеобъемлющий характер, многие из них в принципе не предсказуемы и их возможные негативные последствия могут привести Человечество к глобальной катастрофе. Понимание природы экономики рисков критически важно для выработки действенных политико-экономических механизмов противостояния этим рискам.

Ключевые слова: экономическая теория, политическая экономия, постиндустриальное общество, риски, экономическая система общества, экономика рисков, рынок, экономический кризис, интересы, технологические инновации, глобальные финансы, общественно-функциональные технологии.

\section{RISK ECONOMY}

\section{S. Yu. SOLODOVNICOV}

Doctor in Economics, Professor, Head of the Department «Economics and Law» Belarusian National Technical University Minsk, Republic of Belarus

The article is devoted to the theoretical substantiation of a new social paradigm - risk economy. The current stage of society development and the economy is characterized by a critical increase in financial, technological and technological, political and economic, geo-economic and other uncertainties. It is impossible to understand their ontological nature and reveal the phenomenological specificity without a meaningful definition of the current stage of development of the economic system of society. The article consistently revealed the characteristics of current society, which allowed the author to present a new political and economic concept that characterizes the current stage of development of society and the economythe risk economy. The risk economy is an economy of high-tech and knowledge-intensive industries, characterized by the highest degree of political, economic, technological, financial and environmental uncertainties and risks. These risks are becoming comprehensive, many 
of them are in principle unpredictable, and their possible negative consequences could lead Humanity to a global catastrophe. Understanding the nature of risk economics is critically important for developing effective political and economic mechanisms to counter these risks.

Keywords: economic theory, political economy, post-industrial society, risks, economic system of society, risk economy, market, economic crisis, interests, technological innovations, global finance, social-functional technologies.

\section{ВВЕДЕНИЕ}

В последние десятилетия в мире произошли радикальные технологические изменения, по своему влиянию на эволюцию человечества сопоставимые только с неолитической революцией. Глобальная социально-технологическая революция, свидетелями и участниками которой мы все являемся, по своему значению и последствиям затмевает те лежащие на поверхности проблемы и вызовы, с которыми столкнулось сегодня человечество, страны и народы.

Действительно, в современном мире нарушено геополитическое и политико-экономическое равновесие, сформировался однополярный мир и усиливается борьба за все виды ресурсов. Человечество быстро входит в новую эпоху, содержательно охарактеризовать которую современная экономическая наука оказалась не в состоянии. Сказать, что последняя находится сегодня в гносеологическом кризисе, - не сказать ничего! Ж. Бодрийяр категорически заявляет: «политическая экономия кончается на наших глазах, превращаясь в трансэкономику спекуляции, которая забавляется своей собственной логикой - закон стоимости, законы рынка, производство, прибавочная стоимость, классическая логика капитала, но которая не несет в себе более ничего экономического или политического. Это чистая игра с изменчивыми и произвольными правилами, катастрофическая игра» [1, с. 53].

По существу, сегодня правомерно говорить о гносеологической катастрофе Экономической науки, которая оказалась неспособной содержательно ответить на два главных фундаментальных вопроса политической экономии: в какой экономической системе человечество сегодня живет и какие интересы ее детерминируют? Только после ответа на эти вопросы по существу можно объективно (политически не ангажировано) отвечать на такие частные вопросы как, например: Выживет ли человечество в XXI веке? Можно ли в условиях постоянного роста населения реализовать концепцию устойчивого развития? Насколько близка Объединенная Европа к социальной катастрофе? Не правда ли, нам, современным экономистам, странно читать такое, ведь намного привычней исследовать макроэкономическую динамику, хеджирование валютных рисков, венчурное финансирование и т. д. Безусловно, все это можно и надо делать и это приносит (или может принести) сегодня вполне ощутимую пользу. Но если мы, экономисты, занимаемся этим, не ответив на важнейшие фундаментальные вопросы политической экономии, то вполне можем оказаться в анекдотичной ситуации, когда, уподобившись, например, врачу-дерматологу (который всю медицину сводит исключительно к изучению физиологических функций и строения, а также заболеваний, актуальных для кожи, волос, ногтей, сальных и потовых желез), который, оказавшийся на месте страшной автомобильной катастрофы, оценивает не травмы пострадавших, а состояние их кожи, волос, сальных и потовых желез. К счастью для всех нас таких врачей в жизни не бывает, но к несчастью для человечества таких экономистов подавляющее большинство. Почему так получилось? У нас есть свой, далеко не самый приятный для заинтересованного читателя ответ на этот вопрос, но начнем по порядку. 


\section{РЕЗУЛЬТАТЫ И ИХ ОБСУЖДЕНИЕ}

\section{Экономическая наука как идеологическая доктрина}

Экономическая наука традиционно на протяжении многих десятилетий была и продолжает оставаться идеологической доктриной. При этом экономический текст всегда представляет собой кодированный информационный продукт.

Ум. Эко писал: «Текст - это ленивый механизм, который требует, чтобы читатель выполнил часть работы за него. Иными словами, текст есть приспособление, созданное, чтобы спровоцировать как можно большее количество толкований» [2, с. 51]. Восприятие, а, соответственно, и интерпретация любого текста напрямую зависят от характеристик самого текста и от подготовленности (компетенции) читателя. Это свойство распространяется на любые тексты. Если же речь идет о тексте экономическом - научном, публицистическом или аналитическом, - то в нем обязательно будет несколько уровней кодирования. Казалось бы, это достаточно очевидно: если интеллектуальный и культурный уровень читателя значительно ниже, чем уровень текста, то он его поймет по-своему. Упоминаемый выше Ум. Эко, отмечал по этому поводу, что «двойное кодирование не аристократическая придурь, а способ проявить движение к доброй воле и умственным способностям читателя» [2, с. 57]. В отличие от большинства других (в том числе и научных) текстов в научных и научно-популярных экономических текстах достаточно часто присутствует тройное кодирование. Последнее обстоятельство многократно усложняет определение границ допустимых интерпретаций этих текстов. Остановимся на этом подробнее.

Двойное кодирование присутствует в любом хорошем тексте, в том числе и в художественной литературе. Например, в романе Л. Н. Толстого «Война и мир» есть две системы кодов. Поверхностный (событийный), описывающий последовательность тех или иных действий литературных персонажей, а также те события, при которых они присутствуют. Читая этот роман, подавляющее большинство школьников обращает внимание только на эти события, причем не на все. Несмотря на все старания учителей по русской литературе, безусловно, людей творческих, очень эрудированных и добросовестных большинство школьников по-своему в принципе не могут (да и не хотят) понять второй уровень кодирования этого романа - философию жизни Л. Н. Толстого. Им, девушкам и юношам, не достает не только энциклопедических исторических знаний (эпоха конца XVIII - начала XIX века в школе кажется очень простой и однозначной), но прежде всего жизненного опыта, опыта борьбы и горьких, невосполнимых потерь.

В качестве примера двойного кодирования можно также рассмотреть механику Ис. Ньютона, которая на первом уровне кодирования, раскрывая известные нам всем со школы законы физики, значительно облегчила создание многих машин, механизмов и зданий. На втором уровне кодирования просматривается лапласовский детерминизм, уподобляющий социальные процессы процессам механическим и тем самым упрощая до невероятия, выхолащивая сущность общественных отношений.

Тройное кодирование экономических текстов возникает по множеству причин, перечислять которые в рамках этого текста нет необходимости. Отметим только, что в качестве примера одной такой причины можно привести существование большого количества частных экономических наук, которые отличаются абстрагированием от огромного количества факторов, что является результатом чрезмерного увлечения экономико-математическими моделями. Для того чтобы переложить живой хозяйственный процесс на язык математики, приходится игнорировать неполную рациональность экономического поведения индивидов, неравномерное распределение информации 
между участниками рынка, изменчивость их субъективных оценок, что серьезно влияет на неустойчивость рыночных цен. П. Б. Струве писал по этому поводу: «Поскольку математическое направление политической экономии ударилось в математическую обработку психологических основ экономических явлений, оно применило к многообразному и разнородному миру душевных переживаний совершенно противоречащий его природе прием обезличения» [3, с. 45].

Выделение частных экономических наук теоретически и практически оправдано, поскольку этот процесс отражает усиление разделения и кооперации научного труда в экономической науке. Но это разделение остается правомерным и приносит очевидную выгоду лишь до тех пор, пока выводы частных экономических наук не пытаются расширить за пределы их предмета и объекта. Вопрос заключается не в том, являются ли эти выводы логически возможными, а в том, до какой степени они соответствуют сущности экономических явлений.

Рассмотрим тройное кодирование экономических текстов на примере книги Дж. Кейнса «Общая теория занятости, процента и денег» и порожденной ею науки макроэкономики. Сегодня существует фантастическое обилие мифологизированных экономических явлений, каждое из которых заслуживает если не отдельной книги, то статьи уж точно. Например: рынок и демократия (наиболее близкое по смыслу сочетание - слон и трепетная лань), международный трансферт новейших технологий (ну а это сродни веры в деда мороза) и т. д. Список этих экономических мифов невозможно закончить, т. к. в современной эпохе, эпохе «вселенского обмана» (Ж. Бодрийяр [1] и Ч. С. Кирвель [4]) эти мифы будут плодиться до бесконечности. Итак, мифологизированных экономических явлений и текстов множество. Но нами рассматривается работа Дж. Кейнса. Почему? Да потому, что, во-первых, эта книга являет собой начало нового периода в экономической науке, во-вторых, практически любой экономист о ней слышал, в-третьих, на Дж. Кейнса часто ссылаются для подтверждения своих умозаключений и, в-четвертых, очень немногие читали книгу целиком, и еще меньшее количество ее прочитавших соотносили ее с историческим контекстом, ей предшествующим, и идеологией ее автора. А последнее архи важно для ее понимания.

Сегодня любой студент независимо от того, какую специальность он получает, сталкивается в процессе обучения с макроэкономикой. Если у него экономическая специальность, то минимум дважды - сначала при изучении экономической теории, а затем осваивая собственно курс макроэкономики. Студенты неэкономических специальностей изучают основы макроэкономики в рамках курса экономической теории. Существующая система получения высшего образования порождает дидактическую необходимость упрощения макроэкономики в вузе. В результате чтение такого упрощенного курса, особенно если читающий его преподаватель является жрецом «культа саморегулирующегося рынка», где государство являет себя в обличье «ночного сторожа», приводит к фактическому противоречию тех представлений, которые получает студент о макроэкономике и экономической позиции самого Дж. Кейнса. Прежде чем развивать эту мысль, приведем слова Ум. Эко, полностью соответствующие этому случаю: «Блаженный Августин в труде De Doctrina Cristiana ("О христианской доктрине") пишет: любое толкование части текста является верным, если подтверждается остальной частью того же текста и ложным, если вступает с нею в противоречие. В этом смысле внутренняя согласованность текста самостоятельно контролирует без того неуправляемую интерпретационную энергию читателя» [2, с. 62-63]. А значит, правильность или ложность любой трактовки взглядов Дж. Кейнса надо проверять на соответствие всему его вышеназванному тексту. 
В уже упомянутой выше работе Дж. Кейнс пишет: «Рикардо (теория саморегулирующейся рыночной экономики - C. С.) покорил Англию столь же полно, как святая инквизиция покорила Испанию. Не только его теория была принята Сити, государственными деятелями и Академическим миром, но даже самый спор прекратился. Альтернативная точка зрения совершенно исчезла, и ее просто перестали обсуждать» [5]. Итак, альтернативные саморегулирующемуся рынку точки зрения вообще не рассматривались. Уже интересно. А как же свобода мысли, свобода слова в Великобритании первой трети $\mathrm{XX}$ века? Да никак. Кого из сильных мира сего Туманного Альбиона это может волновать, когда речь идет об их экономических интересах? Наблюдательный читатель по-видимому уже и сам догадался, каков будет ответ... Никого! Или почти никого!

Последуем дальше за Дж. Кейнсом, который пишет: «Полнота победы рикардианской теории - явление весьма любопытное и даже загадочное. Связано это с тем, что теория Рикардо (теория саморегулирующейся рыночной экономики - С. С.) во многих отношениях весьма подошла той среде, к которой она была обращена» [5]. От себя добавим, что, действительно, концепция саморегулирующегося рынка очень близка к обычаям и традициям древних фризов, англов и саксов. Именно потомки этих племен, проживающие на территории Голландии и Англии, первыми создали рыночную экономику, идеальным воплощением которой и стала модель саморегулирующегося рынка. Это не нами первыми замечено и написано. Да и в данном случае неважно, кто первый. Важно, что каким-то непостижимым образом идеология нескольких народов, модель хозяйствования, основанная на их национальных особенностях, стала навязываться всему человечеству как единственно верная. Представляю, как бы удивились сами фризы (пираты, работорговцы и земледельцы в одном лице), если бы узнали, что они породили «общечеловеческую ценность» в виде рынка, где все подчинено росту прибыли...

Далее Дж. Кейнс едко замечает: «Она (теория саморегулирующегося рынка - С. С.) приводила к заключениям, совершенно неожиданным для неподготовленного человека, что, как я полагаю, только увеличивало ее интеллектуальный престиж» [5]. Дж. Кейнс тут абсолютно прав - ничто так не привлекает людей невежественных и недостаточно образованных, но которые при этом хотят казаться интеллектуально развитыми и сведущими, как очень простые и даже примитивные ответы на очень сложные вопросы. Нами уже писалось про это в статье «Культ карго, или Новый объект экономической науки» [6, с. 56-62]. При желании ее можно прочесть.

«Рикардианское учение (теория саморегулирующейся рыночной экономики - С. С.), переложенное на язык практики, - пишет Дж. Кейнс, - вело к суровым и часто неприятным выводам, что придавало ему оттенок добродетели. Способность служить фундаментом для обширной и логически последовательной надстройки придавала ему красоту. Властям импонировало, что это учение объясняло многие проявления социальной несправедливости и очевидной жестокости как неизбежные издержки прогресса, а попытки изменить такое положение выставляло как действия, которые могут в целом принести больше зла, чем пользы. То, что оно оправдывало в определенной мере свободную деятельность индивидуальных капиталистов, обеспечивало ему поддержку господствующей социальной силы, стоящей за власть предержащими» [5]. Хочу подчеркнуть, что проявления социальной несправедливости и очевидной жестокости в процессе становления рыночных отношений (первоначального накопления капитала) в Объединенном королевстве наблюдались за несколько столетий до рождения Д. Рикардо, и его учение лишь легализовало «прогрессивность» этого.

Полагаю, что большинство читателей не представляют себе, о чем идет речь, когда говорится о жестокости того периода - издержки сегодняшнего преподавания европейской истории в школе. Поясню это. Голландия была первой в мире, где почти пять 
веков назад началась промышленная революция. Быстрому росту производства способствовали новые уникальные технологии и практически безграничные рынки сбыта. Нидерланды тогда находились во владении Испанских Габсбургов, которые, оставаясь Испанскими королями, были еще Императорами Священной Римской империи, а также владели другими очень большими территориями в Европе и Америке. В последней Испания награбила столько золота, что в течение XVI века количество этого металла в Европе удвоилось. Итак, есть платежеспособный спрос и есть производственные мощности. Не хватает только сырья для текстильной промышленности - шерсти. Где ее взять? Ответ нашелся быстро - в Англии. Но для этого необходимо было провести огораживание, т. е. согнать фермеров-арендаторов, превратив их поля в пастбища для овец. В результате, как писали в то время английские газеты, «овцы съели людей». Иначе говоря, бывшие фермеры и их семьи превратились в бродяг, поскольку их рабочие руки никому не были нужны. Но если люди не могут найти работу, но хотят есть (т. е. почему-то не хотят законопослушно умереть от голода), то они воруют. А как же «священное право частной собственности»? И власть имущие находят юридическое решение этой проблемы - за любую кражу вешать. И вешали, да еще как вешали. И за украденную буханку хлеба тоже вешали. Не взирая на возраст. Тут, правда, возникла техническая проблема под тяжестью маленьких детей петли не хотели затягиваться. Но английская юридическая машина нашла решение этой проблемы. Был оговорен груз, который привязывался к ногам маленьких англичан, чтобы они могли быть повешенными. Повешенных было много, очень много. Так, по приговорам суда при Елизавете Английской (это при ней адмирал Дрейк разбил Великую Армаду) в Англии были повешены десятки тысяч людей.

В это же время моряков адмирала Дрейка, спасших Англию от вторжения огромной испанской армии, после победы над Великой Армадой несколько месяцев не отпускали с кораблей на берег. Плохо знающий английскую историю читатель спросит: зачем? Да для того, чтобы половина из них умерли от болезней, порожденных антисанитарией, плохой водой и пищей. Ведь умершим не надо платить жалованье, а значит, это позволило значительно сэкономить государственный бюджет. Вот еще один пример рыночной целесообразности и английской рачительности того времени.

Следует отметить, что во имя прибыли имущие классы Великобритании делали вещи и пострашнее, и покровавее. Пожалеем читателей, обладающих слишком хорошим воображением, и не будем здесь приводить эти действительно жуткие примеры.

Но хватит об этом, поскольку тема этой работы несколько иная.

Дж. Кейнс прямо указывает, что «однако, хотя сама доктрина (теория саморегулирующегося рынка - C. C.) в глазах ортодоксальных экономистов не подвергалась до последнего времени (до 30-х г2 $X X$ века - C. C.) ни малейшему сомнению, ее явная непригодность для целей научных прогнозов значительно подорвала с течением времени престиж ее адептов. Профессиональные экономисты после Мальтуса оставались явно равнодушными к несоответствию между их теоретическими выводами и наблюдаемыми фактами. Это противоречие не могло ускользнуть от рядового человека; не случайно он стал относиться к экономистам с меньшим уважением, чем к представителям тех научных дисциплин, у которых теоретические выводы согласуются с данными опыта» [5]. Не правда ли, написано в первой половине XX века, а читается, как будто сказано вчера о наших доморощенных «независимых» экономических экспертах.

Итак, как нами уже отмечалось, первый уровень кодирования учения Дж. Кейнса это уровень ученического, дидактически упрощенного и поэтому поверхностного понимания принципов взаимодействия экономических агентов в национальной экономической системе (на макроуровне). Добросовестный студент вынесет из курса макроэкономики, что существует ряд экономических проблем, решение которых возможно только 
на уровне всей страны, общества в целом. При этом в качестве основных макроэкономических проблем выступят проблемы экономического роста, полной занятости, экономической эффективности, стабильности цен, экономической свободы, справедливости распределения доходов, торгового баланса, охраны окружающей среды и т. д. При этом ученический уровень дает навыки оперирования базовыми макроэкономическими моделями без понимания их абстрактного характера. Поясним это на примере. В кейнсианской макроэкономической модели предполагается, что все субъекты располагают одинаковой информацией, отсутствуют транспортные издержки (все продавцы и покупатели «сидят в одной комнате»), все макроэкономические субъекты (домашние хозяйства, предприятия, государства и заграница") поступают только экономически рационально, отсутствует реклама, нет ограничений и препятствий в доступе на рынки и т. д. и т. п. Очевидно, что такие ограничения не соответствуют реальной хозяйственной жизни в любой стране мира. Если это именно так, а это так, то возникает вопрос: для чего тогда вообще нужна макроэкономика?

Когда нами читается студентам курс макроэкономики, то обязательно подчеркивается, что не так уж сложно объяснить, почему сегодня теория Дж. Кейнса не работает, но необходимо понять, для чего ее надо учить и что из этой теории может пригодиться в практической работе экономиста. На этот вопрос отвечаю так: макроэкономическая теория дает представления об определенных зависимостях между различными макроэкономическими показателями, что облегчает принятие тех или иных решений, поскольку делает возможным сразу же отбросить очевидно неправильные.

Это то же, что хождения девушки на свидания с юношей, который, по ее мнению, мог бы для нее стать хорошим мужем и отцом ее будущих детей. Можно, как многие и делают, не обращать внимание на его «маленькие» слабости: то, что он пьет пиво не реже 2-3 раза в неделю (по медицинским показаниям - это возможно ранняя импотенция), то, что курит, то, что регулярно напивается с «друзьями» до поросячьего визга (верная примета будущего алкоголика), то, что не дарит ей цветы, не открывает перед ней дверь, садится в кафе раньше нее (верная примета сегодняшнего хама), старается поменьше работать и не хочет учиться (лучше поиграть на компьютере) и т. д. Можно не обращать, но если эта девушка по итогу их свиданий не станет очередной «победой» этого юноши на сексуальном фронте, и они поженятся, то вправе ли она будет удивляться через 10 лет, почему у нее муж алкоголик, лодырь и хам? На наш взгляд, нет. Хотя у девушек в нежном возрасте, т. е. до 30-35 лет, могут быть свои ответы на этот вопрос. Но есть другой вариант поведения нашей девушки - увидела что-то из проявлений неуважения к ней, лени, девиантного поведения, отсутствия любви с его стороны и перестала с ним встречаться. Второй вариант поведения логичнее и может значительно поспособствовать счастью в личной жизни. Ну а то, что сэкономит ей время и нервы - это уж точно. Вот также и макроэкономические модели - они позволяют отбросить заведомо невозможные варианты. А вот для выбора самого лучшего варианта этого уже недостаточно.

Второй уровень кодирования учения Дж. Кейнса проистекает из определения макроэкономики как науки, изучающей совместную, взаимозависимую и взаимосвязанную деятельность всех хозяйственных субъектов в рамках целостного экономического орга-

\footnotetext{
* Такой макроэкономический субъект как «заграница» лично у меня при первом знакомстве вызвал очень сильное недоумение. Потом недоумение прошло, но поскольку я долго учил философию, то подсознательное восприятие субъекта «заграница» как ежика изо дня в день идущего среди отары овец на пастбище, чтоб вместе пощипать травки, так и осталось. Казалось бы, нелепица, но факт. Это про ежика. Ну а заграница как экономический субъект хотя и противоречит моим представлениям как политэконома об экономическом субъекте, но очень логично вписывается в теорию Дж. Кейнса.
} 
низма - национальной экономики. Иначе он сам с прозорливостью гения признавал ограниченность применения его теоретических взглядов на практике. Это уже совсем другой подход, второй уровень кодирования текста. Почему? Да потому что Дж. Кейнс, не остановившись на замене социальной парадигмы саморегулирующегося рынка теорией активного государственного регулирования экономики через формирование платежеспособного спроса, попытался пойти дальше - показать, насколько тесно в экономике все связано и взаимообусловлено. В пользу такого прочтения Дж. Кейнса говорят приведенные выше цитаты из его книги. И не только цитаты. И главным образом не цитаты, а теоретическое обоснование тех мер, которые, идя не от теории, а от практики, применил президент Фр. Рузвельт для выхода США из кризиса 1929-33 гг.

Этот экономический кризис был самым страшным в истории США. Огромное количество людей потеряли работу. Вчерашние представители средних классов оказались на грани голодной смерти. Многие умерли от голода. Через какое-то время с трудом удалось в крупных городах организовать для голодающих бесплатную похлебку один раз в день. В огромных количествах за ненадобностью уничтожалось зерно и мясо. Вам показалось, что в нашем перечислении нарушена логика? Это потому, что вы не знаете законы рыночной экономики и не знакомы с теоретическими постулатами макроэкономики. В макроэкономике потребности количественно совпадают с совокупным спросом. Совокупный спрос - это то количество товаров, которое население в данный момент хочет и может купить. Соответственно, если кто-то не может купить себе еду - значит и спроса (потребности) на еду нет.

Но вернемся к кризису 1929-33 гг. К 1932 г. в США 12,5 миллионов полностью безработных (население этой страны тогда составляло 125 миллионов человек). В начале 1933 года число безработных выросло до 17 миллионов человек [7]. «В период наибольшего обострения экономического кризиса, - отмечает Б. Борисов, - каждый третий работающий был лишен занятости. Настоящим бедствием стала частичная безработица. По данным АФТ (Американская Федерация Труда, American Federation of Labor), в 1932 г. полностью занятыми остались всего $10 \%$ рабочих» [7]. Это притом, что страхования по старости и безработице в США в то время не было! В США начинается голод, унесший по разным оценкам около 5 миллионов человеческих жизней [7]. В это время на фоне гибели экономически «излишнего» населения продолжается государственная политика по уничтожению запасов продовольствия: «зерно и просто сжигали, и топили в океане. Так, например, было уничтожено 6,5 млн голов свиней и запахано 10 млн га земель с урожаем» [7]. Это позволило увеличить в США цены на продовольствие более чем в два раза.

По времени это совпадает со сгоном с земли за долги банками 5 миллионов американских фермеров. При этом фермеры не были обеспечены ни работой, ни социальной помощью, ни пенсиями. Примерно каждый шестой из них умер от голода [7].

Да. Вот она историческая иллюстрация действия «невидимой руки рынка». И как же без идеологической поддержки, априори заявляющей о том, что только рыночная экономика является наилучшей формой организации хозяйственной жизни, можно, по существу, оправдать такой «рыночный каннибализм» своего же собственного народа, живущего в «демократическом» американском обществе? Да никак.

Вот и получается, что при выборе модели хозяйствования приоритетной является господствующая идеологическая. Выбор между гуманистической идеологией, в основе которой лежит такой критерий общественного прогресса как снижение социального каннибализма, и идеологией рыночного либерализма, в основе которой лежит социальный каннибализм, - именно это формирует принципы хозяйственной жизни любого государства. Конечно же, нельзя этот принцип абсолютизировать и доводить до логического аб- 
сурда. В любой экономической деятельности всегда сосуществуют две стороны: материально-вещественная и собственно-общественная (социальная). Материально-вещественная сторона представляет собой специализированные средства производства, которыми человек осуществляет свое активное воздействие на природу. Социальная сторона представляет собой персонификацию его материально-вещественной стороны (т. е. социальносубъектное отражение процесса соединения со специализированными средствами производства индивида, обладающего соответствующими способностями и интересами, для их производственного потребления). Взаимосвязь и неразрывность этих сторон очевидна, так как хозяйственная деятельность всегда имеет какое-то материально-вещественное выражение, и оно, как и любое социальное явление, всегда персонифицировано. Даже на основе идентичной технико-технологической базы производства возможно существование различных моделей хозяйствования. Таким образом, проявляется относительная самостоятельность организации и управления производством по отношению к его технологической основе, так как последняя определяет механизм хозяйствования опосредованно.

Отметим также, что неправомерно в любом обществе с относительно высоким уровнем развития хозяйства представлять эту связь как предельно простую и безвариационную. По нашему мнению, следует согласиться с исследователями, которые, в отличие от К. Маркса и его последователей, не признают «жесткую детерминированную связь между развитием производительных сил и социально-экономическими процессами» $[7$, с. 11$]$.

Но вернемся к американскому кризису 1929-1933 гг. Итак, при полном развале народного хозяйства США президент Фр. Рузвельт, видимо, не рассчитывал получить от экономической науки практические рекомендации по выходу из этого кризиса. И действительно, далеко не все из того, что позднее стало прописными макроэкономическими истинами, можно было использовать на практике даже при всем желании. Очевидно, что никакие снижения ставок по процентам или налоговые льготы в сложившейся ситуации помочь не могут. Почти никто не работает, платежеспособной спрос населения катастрофически низок и некому покупать товары, а значит, и нет смысла инвестировать в экономику. А если некуда инвестировать, то какая разница, сколько стоит ненужный инвестиционный кредит. А нет инвестиций - нет и роста занятости. А без занятости нет роста доходов населения. Получается заколдованный круг, но решительность Фр. Рузвельта его разрывает. Предлагается производить за счет государства то, что не надо продавать например, вооружение. И его начинают производить, и в огромных количествах. Производство оружия требует все новые и новые рабочие руки, оборудование и сырье. Для изготовления станков нужны заводы. Для добычи сырья необходимо еще оборудование. И все это также требует новые и новые рабочие руки. Растет занятость. Люди начинают работать, получать зарплату, на которую покупают одежду и еду для себя и членов своей семьи. Экономика начинает работать! Почти по теории Дж. Кейнса.

Почему почти?

Да потому что в стране по-прежнему миллионы безработных, бродяг и бандитов. С ними надо что-то делать. И решение находится - «общественные работы» Фр. Рузвельта. На «общественных работах под эгидой Администрации общественных работ (PWA) и администрации гражданских работ Civil Works Administration - CBA (это строительство каналов, дорог, мостов зачастую в необжитых и болотистых малярийных районах), с единовременным числом занятых до 3,3 миллиона» [8], а всего через них прошло 8,5 млн человек [7] - это не считая собственно заключенных. Ряд исследователей с высокой степенью достоверности отмечает схожесть режима на этих работах с режимом ГУЛАГА. Проверить это сегодня нельзя, так как данные об этом до сих пор относятся к государственной тайне США. Но то, что утекает в открытый доступ, способно вызвать 
ужас. Так, например, возглавляющий Администрацию общественных работ, министр внутренних дел Г. Икес, «с 1932 года заключил в лагеря для безработной молодёжи около двух миллионов человек (!), причем из 30 \$ номинальной заработной платы обязательные вычеты составляли 25 \$. Пять долларов за месяц каторжного труда в малярийном болоте. Достойная плата свободным гражданам свободной страны» [7].

Выход из кризиса был найден, но найден не в рамках методологии книги «Общая теория занятости, процента и денег» [5], не на основе некоторых ее идей и моделей (некоторые исследователи считают, что Фр. Рузвельт самостоятельно пришел к выводам, созвучным теоретическим взглядам Дж. Кейнса), но исходя из жизни, исходя из совпадения взглядов Ф. Рузвельта и Дж. Кейнса на национальную экономику как на живой организм.

Нам бы не хотелось, чтобы читатель, не очень хорошо знающий историю США, сделал вывод, что после всех этих усилий американская экономика стала быстро развиваться. Это не так. Экономика США находилась в застое до начала Второй мировой войны. И только после ее начала американский военно-промышленный комплекс дал толчок бурному росту экономики страны.

Прежде чем перейти к третьему уровню кодирования учения Дж. Кейнса, приведем соответствующую этому случаю цитату Ум. Эко: «когда текст создается не для одного конкретного адресата, а обращен к сообществу читателей, автор наперед знает, что его слова будут истолкованы не согласно его замыслу, но в соответствии со сложной стратегией взаимоотношений в которую вовлечены эти самые читатели, обладающие социальным достоянием в виде языковой компетенции, т. е. знания родного языка. Под "социальным достоянием" я $\left(V_{\mathcal{M}}\right.$. Эко - C. $C$.) подразумеваю не только некий состоящий из набора грамматических правил язык, но всю энциклопедию, то есть сумму тех знаний, что накоплены в процессе использования этого языка: порожденные им культурные традиции и набор всех существующих и существовавших ранее интерпретаций множества написанных на этом языке текстов, включая текст, читаемый в данный момент» [2, с. 67-68]. Из этой цитаты, по нашему мнению, следует неоднозначность, вариативность взаимоотношений внутри триады: автор - текст - читатель.

Считаем, что в духе Ум. Эко можно рассматривать текст Дж. Кейнса не как застывший (мертвый) объекта, а как живое, постоянно трансформирующееся и до конца не познаваемое явление. Причем эта живость может порождаться и сохраняться только сегодняшним читателем, поскольку Дж. Кейнса уже давно нет, а без него его текст переписывать недопустимо. Приведем в подтверждение правильности нашего умозаключения еще одно высказывание Ум. Эко: «Акт чтения обязан принимать во внимание все упомянутые элементы, пусть даже отдельный конкретный читатель вряд ли способен совместить их в себе. Таким образом, каждый акт чтения представляет собой сложную транзакцию между компетенцией читателя (читательским знанием о мире) и тем типом компетенции, которую данный текст постулирует, чтобы быть истолкованным самым "экономичным" образом - так, чтобы интерпретация строилась на максимальном понимании написанного и поддерживалась контекстом» [2, с. 68-69]. Итак, поскольку за примерно 70 лет после первого опубликования книги Дж. Кейнса «Общая теория занятости, процента и денег» мир радикально изменился, а, соответственно, наше (как читателей) знание о мире иное, то опираясь на контекст этой книги, можно позволить себе ее постмодернистскую интерпретацию.

Считаем, что поскольку достаточно пояснили методологию своих интерпретаций, то можно перейти к изложению нашего видения третьего уровня кодирования в тексте Дж. Кейнса. Как нами было написано выше, Дж. Кейнс прямо указывал на то, что рикардианская теория использовалась для оправдания имущими классами проявлений соци- 
альной несправедливости и очевидной жестокости сложившейся рыночной системы хозяйствования, т. е. социальная парадигма саморегулирующего рынка направлена на апологетику преимущественной реализации вполне конкретных классовых интересов. Он также рассматривал национальную экономику как живой организм. Казалось бы, надо сложить эти два тезиса и получится очевидный вывод, что роль государства в экономике не ограничивается макроэкономическими целями и задачами, но и направлена на реализацию интересов определенных классов и иных социальных групп.

Мы не следуем слепо за К. Марксом в его трактовке взаимоотношений классов как непрерывной классовой борьбы. История дает нам множество примеров классового сотрудничества и мира. Речь идет о другом. О том, что даже в социальном государстве существует необходимость перераспределения экономических благ от одних групп к другим, но это перераспределение направлено на усиление социальной справедливость (а не на рост социального каннибализма) и накопления социального капитала на уровне общества в целом и в отдельных локальных сообщества, а значит, способствует усилению жизненности общества в целом, а также увеличивает внутренний спрос за счет роста потребления домашних хозяйств.

Но вернемся к Дж. Кейнсу. С прозорливостью гения он подошел к этой проблеме, почти обозначил ее и даже дал часть инструментария для ее решения. Это и есть третий уровень кодирования текстов Дж. Кейнса. Но дальше он пойти не смог, не смог последовательно развить эту свою идею. Помешала та культурная среда, в которой он рос и жил, классовая принадлежность и, возможно, то, что в тот период на Западе нельзя было писать о социально-классовой дифференциации общества и не быть при этом обвиненным в марксизме. А это обвинение еще длительное время до и после смерти Дж. Кейнса приводило к превращению в изгоя в западной академической и университетской среде. Например, ведущий французский социолог П. Ансар в своей книге «Современная социология» так описывает взаимоотношения западной обществоведческой мысли и марксизма: «В целом с 1945 г. до 70-х г. во Франции, Италии, как и в ФРГ и США, многие исследователи в области общественных наук, не связывая себя догматически с отдельными деталями марксовых положений, извлекли из них самое существенное с намерением преодолеть границы узкого экономизма (Ж.-П. Сартр, 1960) либо в целях подорвать авторитет функционалистских консервативных моделей (Ч. Миллс, 1959; Ю. Хабермас, 1968)» [9, с. 136]. Далее П. Ансар отмечает, что «1970-1980-е гг. отмечены отходом от этой содержательной стороны марксизма в общественных науках, что было связано с различными причинами, в которых исторические события сыграли не последнюю роль» [9, с. 136]. Таким образом, и Дж. Кейнс не смог полностью преодолеть рыночную идеологию (которую подверг очень убедительной критике в своих работах) и это существенно повлияло на его теоретические воззрения. А экономическая наука сегодня попрежнему остается преимущественно идеологической доктриной, выражая политико-экономические интересы определенных общественных групп и социальных классов.

\section{Рынок как политико-экономический феномен}

На сегодняшний день, несмотря на многовековую историю исследования рыночных отношений общественные науки в целом и экономическая теория в частности так и не смогли выработать единого понимания рынка. «Подходы к его определению сильно различаются, - отмечает В. В. Радаев, - и в результате практически каждому из нас в зависимости от контекста случается называть "рынком" принципиально разные явления» [10, с. 19]. Сегодня «наряду с трактовкой рынка как "территории обмена", - поясняет 
названный автор, - используется его понятие как формы хозяйства, уже не столь привязанное к определенному месту. А рядом с ними располагается неоклассическая экономическая концепция "идеального рынка", в которой обмен осуществляется автоматически, без каких-либо сил трения. В последнем случае рынок предстает как механизм спроса и предложения, который действует в любых территориальных или отраслевых контурах. Причем речь идет не просто об агрегированной совокупности индивидуальных актов обмена, но об относительно автономной от остальной части общества и самодостаточной системе со встроенным механизмом саморегуляции» [10, с. 20-21]. За счет такого методологического приема происходит превращение рынка «из эмпирического объекта в аналитическую модель с достаточно абстрактными основаниями» [10, с. 21]. Причем в этой модели «социальным условиям отводится незавидная роль внешних факторов или, того хуже, тех самых сил трения, которые снижают эффективность саморегулирования» [10, с. 21]. Таким образом, живые люди, индивиды выбрасываются из предмета экономической теории. Им на смену приходит некий абстрактный «экономический человек» с достаточно примитивными потребностями и мотивами, которые легко могут быть переложены на математический язык.

Было бы несправедливо утверждать, что ученым-экономистам удалось рассмотреть методологическую ограниченность парадигмы «саморегулирующегося рынка», а значит и ее теоретическую, историческую (достаточно вспомнить хотя бы, как в эпоху колониальных империй экономические проблемы метрополий решались за счет колоний, когда «невидимая рука рынка» приобретала форму дредноутов и кавалерийских полков) и практическую несостоятельность лишь в начале XXI века. Уже в начале прошлого века набирающее силу институциональное направление (тогда еще достаточно синкретичное в своих теоретико-методологических подходах) по существу явилось гносеологической рефлексией на господствовавшее тогда на Западе направление «чистой экономики» в форме маржинализма. Оппозицию маржинализму с его чрезмерно абстрактным, рационалистским, количественным подходом к анализу экономических систем на Западе в это время составили так называемые «периферийные» школы в экономической науке - германские новейшая («юная») историческая и социальная школы и ранний институционализм (заметим, не только американский, ибо сюда также можно отнести и англичанина Дж. Гобсона, и француза Ф. Симианда с его учениками Г. Пиру и Б. Ногаро) [11, с. 44]. Данные направления экономической мысли объединяются сегодня «понятием "институциональное направление в экономической науке" (или институционализм в широком смысле, дабы не путать его с собственно институционализмом, или институционализмом в узком смысле, родоначальником которого был Т. Веблен)» [11, с. 44].

В России идеи и принципы институционального направления были представлены в трудах бывших «критических марксистов» С. Н Булгакова («Философия хозяйства», 1912) [12], М. И. Туган-Барановского («Социальная теория распределения», 1913) [13] и П. Б. Струве («Хозяйство и цена», 1913-1916) [14]. Развитие в России параллельно с институционализмом маржиналистского направления «сдерживалось, - как подмечает Л. Ипполитов, - как в силу объективных причин (недостаточная степень развития товарного хозяйства и капитализма, засилье феодальных пережитков, обострение комплекса социально-экономических, политических и культурных противоречий накануне революции), так и особенностями психологии русского образованного общества, большей части которого были чужды принципы индивидуализма, эгоизма, тедонизма и т. д.» [11, с. 45]. А. Г. Худоркомов прямо заявляет по этому поводу, что «в сложившейся ситуации удивительно не то, что маржинализм в России не превратился в доминирующее направление, а то, что он вообще сформировался как отдельное течение, сопряженное с самого начала с передовыми экономико-математическими исследованиями» [15, с. 840]. 
На основании проведенного анализа П. Б. Струве сумел показать, что концепция равновесия и анализ равновесных состояний в экономике (один из главных принципов маржиналистской теории) была порождена философией XVII-XVIII вв. (Бэкон, Декарт, Гоббс, Ньютон) и утвердившимся в экономической науке механистическим мышлением и учением о «естественном законе» [11]. По П. Б. Струве, идея равновесия может быть представлена в экономическом мышлении двояким образом: «Во-первых, как идея онтологическая, идея о присущем с необходимостью экономическому процессу свойстве, которое господствует над его феноменами и ими управляет. И, во-вторых, как идея чисто феноменологическая, как идея особого явления, равноправного со всеми другими экономическими феноменами, явления, представляющего не общий закон экономической жизни, а некое возможное и вероятное ее "состояние"» [16, с. 6]. Таким образом, маржинализм и классическая политическая экономия приписывают равновесию значение некой сущности стоящей над экономическими явлениями и управляющими ими. Отрицая механистический подход к анализу экономических феноменов, П. Б. Струве подчеркивал, что «хозяйственная жизнь слагается из множества отдельных действий хозяйствующих субъектов, которые, будучи в общем и формально мотивами так называемого хозяйственного расчета, в своей индивидуальности, "микроскопической" конкретности случайны в точном смысле этого слова. "Микроскопически" действия продавцов и покупателей определяются расчетом, ориентированным с разной, бесконечно дифференцированной, осведомленностью о положении рынка, столь же дифференцированной разумностью; и с неопределенной подвижностью во времени субъективных оценок (проектов, или заявок цен) и их окончательных денежных выражений, или значений, каковыми являются реализованные, "сделанные" цены. Эти неопределенно многообразные цены имеют тенденцию к единству, или "равновесию", это единство и эти состояния "равновесия" неустойчивы, подвержены постоянным и непрерывным колебаниям» [16, с. 12-13]. П. Б. Струве выделил те черты, которые игнорировались маржиналистской теорией экономического равновесия - «...неполная рациональность экономического поведения, ассиметричное распределение информации среди участников рынка, изменчивость их субъективных оценок и, как следствие, рыночных цен» [11, с. 49]. В результате проведенного анализа П. Б. Струве сумел доказать теоретико-методологическую несостоятельность маржинализма как механистической и статической концепции, устраняющей факторы времени и изменения из экономического анализа [11, с. 49-50].

П. Б. Струве также сумел убедительно показать ограниченность экономико-математических методов. «Поскольку математическое направление политической экономии, указывает этот автор, - ударилось в математическую обработку психологических основ экономических явлений, оно применило к многообразному и разнородному миру душевных переживаний совершенно противоречащий его природе прием обезличения» [3, c. 45]. Высказываясь по данному вопросу, Л. Ипполитов, в частности, подчеркивает, что «вопрос заключается не в том, является ли "механический" (включая сюда и "математическое рассуждение") подход к экономическим процессам логически возможным, а в том, соответствует ли он существу экономических явлений, текучей и прерывистой природе "экономической материи"? На этот вопрос Струве отвечает решительно отрицательно»[16, с. 16].

П. Б. Струве пишет: «В экономике какие-то подлежащие определению в каждом отдельном случае "индивиды" должны быть сосчитаны, сведены в разряды и категории, т. е. именно трактуемы как индивидуально весьма различные единицы, объединяемые лишь по "признакам" в некие статистически обозримые совокупности» $[16$, с. 16]. Это может быть осуществлено только с помощью статистических методов. «Эта всесторонняя взаимозависимость непреодолима для "механического" или "динамического", в про- 
тивоположность статистическому рассмотрению. Если мы к этому прибавим, что экономические «индивиды», с точки зрения экономического познания, не являются абсолютно детерминированными какими-нибудь известными нам силами, а «"контингенты" <..> "самочинны" или "бесчинны", то эти два условия необходимы и достаточны для выставления методического постулата о том, что точное познание в экономике возможно только либо в форме статистической разработки, либо в форме фактического описания неисчислимых статистически феноменов и сторон» [16, с. 16]. Порок маржиналистской теории, по справедливому замечанию П. Г. Струве, коренится в том, что в ней, как и во всех концепциях механически-математической политической экономии, не усматривается логическая природа эмпирического знания, к области которого относится и политэкономия. Они рассуждают more geometrico в области, где плодотворна либо чистая индукция, либо статистический подход [3, с. 49].

Далее названный автор поясняет, что несоответствие метода исследования у маржиналистов (добавим, как сегодня у неолибералов и прочих «чистых экономистов»), связано «со смешением наук о реальном бытии во времени, или знания апостериорного, к которому относится и политическая экономия, с науками об идеальном и безвременном бытии, каковыми являются математика и логика, представляющие знание априорное» $[11$, c. 56]. П. Г. Струве также подчеркивает: «Эмпирическая наука может строить общие понятия, но она не может вовсе отвлекаться от "действительности", в отличие от математики. Самая природа предмета ставит поэтому и "абстракции", и "дедукции" во всякой эмпирической науке < ..> совершенно другие границы, чем в математике» [3, с. 36].

Если исходить из критериев логичности и аргументированности участников дискуссии о коренных методологических пороках маржинализма, неоклассики и т. д., то доказательств этому предостаточно. Вместе с тем, неправомерно сводить все дискуссии о природе рыночных отношений лишь к поиску научной истины. Ученые-экономисты тоже люди. Они родились и воспитывались в определенной социально-культурной среде, обладают мотивацией, различными потребностями и интересами, наконец, их исследования финансируются из различных источников (а у субъектов, которые их контролируют, есть вполне реальные экономические потребности и интересы) и т. д. Все это также позволяет говорить о том, что экономическая теория не может не быть идеологической доктриной. При этом главный вопрос заключается не в том, в какой степени то или иное экономическое учение пропитано идеологией (от последней все равно никуда не денешься), а в том, чья это идеология и насколько она соответствует объективности методов и результатов исследования хозяйственной жизнедеятельности. Таким образом, по нашему мнению, научное сообщество фаталистически обречено не только на постоянный поиск объективных закономерностей развития общества и его экономической системы, но и на выделение «ложных» концепций и преднамеренных концептуальных упрощений, обслуживающих глобальные экономические интересы вполне конкретных государств, классов, социально-экономических групп, а иногда и конкретных индивидов.

С точки зрения объективности экономической науки (а это по существу синонимично тому, насколько эффективно она может выполнять такие свои функции как критическая и прагматическая) не важно, случайно или целенаправленно возникли и развиваются социальные парадигмы, относимые сегодня к «экономическому империализму» [17]. Для нас важнее то, что эти теоретико-методологические подходы, например, сводящие экономические функции государства к роли «ночного сторожа», деформируют сознание части научного и научно-педагогического сообщества, понижают доверие к белорусской модели развития, снижают социальный потенциал белорусского общества, т. е. понижают продукционный эффект от социального капитала, накопленного на уровне социума, а значит, угрожают экономической безопасности страны. 
В 1960-1970-е гг. идеальной рыночной модели, очищенной от каких-либо социальных факторов, был придан фактически универсальный характер. «С ее помощью, отмечает В. В. Радаев, - стали объяснять самые разные типы существующих рынков вне зависимости от исторической и культурной специфики хозяйства и общества» [18, с. 28-37]. Г. Беккер и его последователи в рамках «экономического империализма» начинают активно использовать данную модель за пределами анализа собственно экономических отношений в их былом понимании [17; 19, p. 395-396; 20; 21]. Так, например, Г. Беккер, заявляет: «Когда мужчины и женщины решают вступить в брак, завести детей или развестись, они пытаются повысить свое благосостояние путем взвешивания сравнительных выгод и издержек. Таким образом, они заключают брачный союз, если ожидают, что это повысит степень их благополучия по сравнению с тем, если бы они оставались в одиночестве, и разводятся, если это должно привести к росту их благосостояния» [19, p. 395396]. Теоретиками общественного выбора начинает трактоваться политика как рыночный обмен [22, с. 22]. Принципы, используемые при анализе рыночного обмена, распространяются на все сферы общественной жизни. Это формирование своего рода рыночной идеологии, как справедливо замечает В. В. Радаев, «...подпитываемой духом экономического либерализма. Жизнь начала уподобляться рынку, представленному в виде достаточно абстрактной конструкции» [10, с. 22]. Как результат - возникновение серьезной методологической альтернативы, разделившей по существу всех современных обществоведов на два типа. Суть данного разграничения заключается в следующем: «рассматриваем ли мы рынок, прежде всего, как универсальную аналитическую модель с весьма ограниченным числом переменных, предназначенную для объяснения неких существенных экономических связей, или нашим объектом выступают "реальные" рынки... для описания которых мы используем разные аналитические модели с большим общим числом переменных» [10, с. 22].

Поскольку принцип универсализма не отвечает ни принципам современных системных исследований социальных объектов, ни историческим реалиям, то мы в своих дальнейших исследованиях будем исходить из взгляда на системы хозяйствования как на многоукладные, сочетающие в себе универсальные и национальные особенности. Современное рыночное хозяйство характеризуется сверхиндустриальным (индустрия 4.0) или постиндустриальным технологическим укладом, множеством форм (в том числе и смешанной) собственности, экономической обоснованностью, декларируемой свободой предпринимательства и обязательным вмешательством государства в экономику. Названная форма хозяйствования выступает как результат государственного и социального регулирования, порождающего огромное разнообразие исторических форм рыночных институтов. Современный рыночный механизм функционирует в условиях установления относительных равновесия и стабильности посредством экономических средств государственного регулирования, связанных как с особенностями функционирования экономики на макроуровне (циклические колебания, экономический рост и др.), так и несовершенством рыночного механизма.

Рынок представляет собой специфический уклад хозяйствования, существующий наряду с другими его формами. Государство выступает как конфигуратор рынка. Степень его воздействия вариативна, но в любом случае речь идет не просто о весомом, но о конституирующем влиянии государства на совокупность рынков - посредством установления формальных правил и способов их поддержания, осуществления перераспределительных функций и прямого участия в хозяйственных процессах [23, p. 23]. Государство не просто вмешивается в рыночные отношения. Оно создает условия для возникновения и развития рынков, являясь во многом внутренним элементом процесса их формирования и трансформации, действуя на началах встроенной автономии (embedded autonomy) [24; 25; 26; 18, c. 39]. Современное рыночное хозяйство, а точнее современное 
преимущественно рыночное многоукладное хозяйство, представляет собой сложную систему социально-экономических, политических и иных институтов, персонифицированных в социально-экономических субъектах (индивидах, группах, классах). Хозяйственная эффективность взаимодействия названных субъектов во многом предопределяется накопленным в обществе социальным потенциалом и институциональными формами его капитализации. Социальных капитал, способы и формы его присвоения, оптимальность распределения и прочее выступают основой для сокращения (или увеличения) транзакционных издержек в народном хозяйстве.

\section{Онтологические и феноменологические характеристики современного общества}

Сегодня для обозначения контуров качественно нового состояния современного нам общества наиболее распространенным является социальная парадигма «постиндустриального общества». Поэтому остановимся на этой теории подробно. Согласно взглядам родоначальника постиндустриального подхода Д. Белла [27], переход к постиндустриальной экономики не означает исчезновения аграрного и индустриального укладов, а сохранение последних, но уже не как доминирующих, а как периферийных. При этом постиндустриальный уклад становится доминирующим. В итоге усиливается сложность социально-экономических процессов.

В научной литературе отмечается, что методологические принципы концепции постиндустриализма были заложены К. Кларком и Ж. Фурастье в конце 1930-х - середине 1940-х годов. Согласно их взглядов, «...в общественном производстве выделяется триада секторов (первичный - сельское хозяйство; вторичный - промышленность и третичный - сфера услуг). Переход от одного сектора к другому, по их мнению, осуществим благодаря, во-первых, экономическому развитию, приводящему к относительным изменениям в спросе на продукцию секторов, во-вторых, росту производительности, отражающемуся на относительном изменении спроса на трудовой ресурс в разных секторах. Со временем доминантным становится третичный сектор - как с точки зрения доли занятых в совокупной занятости, так и с позиции удельного веса продукции данного сектора в ВВП» [28, с. 36].

В работах более поздних авторов акцент делается на качественной характеристике постиндустриального общества, что привело к возникновению таких понятий, как «информационное общество» (Ф. Махлуп) [29]; «общество знаний» (Н. Штер) [30] «технотронное общество» (3. Бжезинский) [31]; «сетевое общество» (М. Кастелльс) [32]; «экологический постиндустриализм» (Т. Росзак) [33] и др. Поскольку концепция постиндустриального общества отличается глобальностью методологических принципов и масштабом охватываемых проблем, то она не может быть однозначно отнесена ни к экономической, ни к социологической, ни к политической науке [34].

В работах последователей Д. Белла отмечается, что становление и развитие постиндустриального общества сопровождается, во-первых, изменением характера промышленного производства от массового изготовления до гибкого специализированного в ответ на технологические инновации, во-вторых, переходом роли локомотива развития экономики от промышленности к сектору услуг и, в-третьих, значительным увеличением значения знаний для развития экономики.

Большое внимание современными учеными, сторонниками постиндустриального направления, начинает уделяться механизмам достижения постиндустриального общества. Как отмечает по этому поводу О. В. Вередюк, «в исследованиях постиндустриальных тенденций в целом можно обнаружить вектор на дробление и детализацию постиндустриальной проблематики. К ведущим отечественным (российским - C. C.) научным 
экспертам постиндустриализма можно отнести В. Л. Иноземцева, А. В. Бузгалина, А. И. Колганова, В. А. Медведева, Р. М. Нуреева. В их работах не только рассматриваются методология исследования постиндустриального общества, проблемы адаптации экономики России к новым условиям в целом, но и уделяется внимание проблематике отношений занятости. Среди отечественных (российских - C. С.) ученых, чьи исследования непосредственно касаются вопросов занятости и рынка труда, - Р. Л. Агабекян, В. Е. Гимпельсон, Р. И. Капелюшников» [28, с. 37].

Как известно, причиной постиндустриальных изменений в производстве являются изменения в технологиях: преобладание наукоемких технологий над трудоемкими и капиталоемкими. Активное развитие наукоемких технологий ведет к росту спроса на высококвалифицированных работников и снижению - на низкоквалифицированных работников. Вместе с тем при оценке перспектив развития занятости необходимо учитывать, как справедливо отметил М. Кастельс, что распространение информационных технологий не снижает общий уровень занятости [35], хотя и значительно изменяет структуру занятости (рабочая сила все активнее перемещается в сферу услуг).

Сторонниками постиндустриальной социальной парадигмы, а также «производными» от нее теоретическими построениями («информационное общество», «экономика знаний», «посткапиталистическая экономика» и т. д.), отмечается, что быстрое развитие технологий требует соответствующих изменений специализации профессиональных навыков, т. е. возникает проблема подготовки и переподготовки кадров. Рост уровня специализации навыков в условиях быстрых изменений квалификационных требований приводит к снижению взаимозаменяемости труда. Соответственно, возрастают издержки замены интеллектуального труда, которые более высоки по сравнению с издержками замены физического труда. Изменения в производстве, вызванные технологическими новациями, оказывают множественное и не всегда однозначное влияние на занятость, которое проявляется, прежде всего, в изменении структуры спроса на труд, а также в характере производственных отношений [36, с. 39].

Последователи этой парадигмы отмечают, что при переходе к постиндустриальному обществу повышается роль знаний, что выражается в изменении соотношения факторов производства (ведущее место занимают знания и информация) и имеет место трансформация структуры добавленной стоимости (в ней возрастает доля стоимости, созданная интеллектом).

Разберем последний тезис на предмет его методологической обоснованности. Прежде всего, важнейший посыл Д. Белла о том, что при переходе к постиндустриальному обществу повышается роль знаний представляется безусловно правильным. Но именно в этой безусловной правильности и заключается его методологическая погрешность. Поясним это подробнее. Принцип возрастания роли знаний по мере технического прогресса человеческого общества неизменно действует, начиная с каменного века, порождая при этом все более сложные формы разделения и кооперации труда. Нами уже отмечалось, что «по мере ускорения НТП, приведшего к НТР, смена доминирующих технологических укладов происходит все быстрее [37, с. 302]». При этом, как известно, «научно-технические достижения, разделение и кооперация труда, субординация и ординация между индивидами и многие другие социальные феномены и институты тем успешнее способствуют экономному получению человечеством необходимых вещества и энергии из природой, чем выше уровень социального прогресса в обществе. По мере усложнения общества разделенного труда названная зависимость усиливается [38, с. 2]». Повышение роли знаний о природе, человеке и обществе не являются феноменологической особенностью современного (в терминологии Д. Белла - постиндустриального) общества, а напротив, 
сопровождает Человечество на протяжении всей его истории [39]. Таким образом, в данном случае у Д. Белла обнаруживается методологическая ошибка, а именно общее (возрастание роли знаний) приравнивается к частному (главному феноменологическому признаку современного общества).

Критически рассмотрим тезис последователей Д. Белла о переходе в постиндустриальном (современном) обществе роли локомотива развития экономики от промышленности к сектору услуг. По нашему мнению, все экономически развитые страны в этом контексте сегодня могут быть условно разделены на два типа:

во-nервыx, это страны, которые исходя из стратегии приоритетного развития промышленности развивают сверхиндустриальную экономику (в ФРГ - это индустрия 4.0 [40]), при этом опережающими темпами развиваются услуги промышленного характера. «Исходя из понимания экономической природы услуг промышленного характера как хозяйственного блага в форме действия, обеспечивающего создание, развитие и функционирование технологий, связанных с разработкой, производством, реализацией и сервисным обслуживанием промышленной продукции, - справедливо отмечает Ю. В. Мелешко, развитие организационно-экономического механизма оказания этих услуг осуществляется в тесной взаимосвязи с национальным промышленным комплексом. Вместе с тем услуги промышленного характера являются межотраслевой деятельность, поскольку в зависимости от организационной формы их оказания и особенностей статистического учета могут относиться и к промышленному производству, и к сфере услуг» [41, с. 84-85]. Названный автор также подчеркивает, что эти услуги сегодня «...формируются ключевые факторы конкурентоспособности промышленности, в частности, новые производственные и организационно-управленческие технологии (информационные, консалтинговые, инжиниринговые, логистические, маркетинговые и т. д.), направленные на качественное развитие товара и/или сокращение затрат. Эти услуги, присутствуя на каждой стадии создания добавленной стоимости промышленной продукции (разработка и внедрение продукции в производство, её изготовление, сбыт и послепродажное обслуживание), являются неотъемлемой частью промышленного производства» [42, с. 39].

Итак, в странах, проводящих промышленную политику, направленную на создание и развитие сверхиндустрии, сфера услуг настолько тесно переплетается со сферой промышленного производства, дополняя и развивая друг друга, что статистически они не всегда могут быть разграничены. В научной литературе по этому поводу отмечается, что «в зависимости от организационной формы оказания услуг промышленного характера один и тот же вид деятельности может быть статистически учтен и в промышленном производстве (в случае оказания этих услуг собственными структурными подразделениями предприятия), и в строительстве или в сфере услуг (в случае инсорсинга и аутсорсинга услуг промышленного характера)» [43, с. 127-128]. Таким образом, на практике наблюдается статистический учет одних и тех же услуг промышленного характера как в сфере промышленного производства, так и в сфере услуг. Более того «внутренние изменения характера производства, а именно возрастание значения услуг промышленного характера, также приводят к росту сектора услуг, не связанному, однако, с деиндустриализацией экономики. Сегодня рост сферы услуг обеспечивается не столько за счет спроса домашних хозяйств на услуги как конечные потребительские товары, что было характерно для сервисизации экономики, начавшейся в середине XX века, или за счет финансово-спекулятивного сектора, а во многом за счет спроса на услуги промышленного характера, представляющие собой промежуточное потребление промышленного производства» $[44$, с. 72]. На сегодняшний день трактовка постиндустриальной социальной парадигмы Д. Белла как создание сервисной экономики вместо экономики индустриаль- 
ной подвергается справедливой критике многими экономистами. В частности, Т. В. Сергиевич отмечает: «Наиболее перспективным направлением развития экономики с точки зрения устойчивого развития является возрождение промышленности на новых технологических основах, а именно не отказ от индустрии, а переход к неоиндустриальной парадигме, основанной на внедрении в производство высоких технологий, экологичности» [45, с. 52]. Нами также отмечалось, что «говоря о новой роли сектора услуг в постиндустриальном обществе, в том числе и о росте создаваемого в этом секторе ВВП, увеличения количества занятых и т. д., необходимо принимать во внимание то, что более половины позиций, связанных с услугами (это инженеры, техники, программисты и прочие, работающие в промышленности), по сути, относятся к вторичному сектору экономики» [46, с. 6];

во-вторых, это страны, которые исходят из стратегии построения «классической постиндустриальной экономики», сопровождаемой относительной деградацией национального промышленного комплекса (например, Великобритания) и опережающим развитием услуг «не промышленного характера»: финансово-спекулятивные, социальные, традиционные и т. д. Критикуя такую модель социально-экономического развития, Ю. В. Мелешко справедливо отмечает, что «абсолютизация значения сферы услуг в экономическом развитии общества, имевшая место в середине XX века, показала свою несостоятельность, что положило начало тенденции реиндустриализации в экономически развитых странах. При этом наметившаяся реиндустриализация характеризуется не просто увеличением доли промышленного производства в структуре ВВП и занятости, а установлением приоритета в развитии наукоемких и высокотехнологичных производств (таких как ракетно-космическая промышленность), неотъемлемым элементом которых являются услуги, в частности, услуги промышленного характера» [47, с. 38]. Названный автор поясняет, что «переход доминирующего положения к третичному сектору экономики наблюдается сегодня в большинстве экономически развитых и развивающихся странах. Вместе с тем мировой опыт показал, что увеличение доли сферы услуг в ВВП и структуре занятости населения автоматически не обеспечивает стабильное социально-экономическое развитие и не является само по себе фактором экономического роста. В этом контексте представляется более перспективной модель хозяйствования Германии, экономика которой относится на сегодняшний день к сверхиндустриальной, поскольку ее ядром являются высокотехнологичный индустриальный комплекс, а сфера услуг нацелена, прежде всего, на обслуживание потребностей промышленности» [48, с. 51]. Немецкие авторы отмечают по этому поводу: «Благодаря Индустрии 4.0 возникают новые формы создания добавленной стоимости и новые бизнес-модели. Старт-апы и мелкие предприятия получают здесь шансы, развивать и предлагать смежные услуги» [40].

Соотнесение вышеприведенной типологии стран и теории постиндустриального общества позволяют сделать вывод, что Д. Белл и его последователи в своих обобщениях игнорировали опыт стран первого типа (со сверхиндустриальной экономикой), возводя особенности развития страны второго типа (с сервисной экономикой) в разряд общего. При этом у апологетов постиндустриальной социальной парадигмы обнаруживаются следующие методологические просчеты: игнорирование исторического опыта, а именно опыта развития стран со сверхиндустриальной экономикой, и отождествление частного и общего, т. е. феноменологические особенности стран с сервисной экономикой возводятся в разряд всеобщих онтологических закономерностей. Последнее, по нашему мнению, стало возможным, по причине преобладания в теоретических построениях Д. Белла либерально-рыночной идеологии, перерастающей у некоторых его последователей в беккеровский рыночный фундаментализм. В свое время нами уже писалось по этому поводу: «Постиндустриальное общество является качественно новым состоянием в развитии человеческого общества, поэтому при исследовании его социально-экономической 
составляющей возникают дополнительные сложности (по сравнению с индустриальной и доиндустриальной стадиями), обусловленные, во-первых, коротким историческим периодом его существования и, во-вторых, высокой степенью идеологической заданности (в том числе апологетики "протестантского фундаментализма") в работах зарубежных исследователей, описывающих страны золотого миллиарда» [49, с. 86].

Названные методологические погрешности достаточно часто встречаются в общественных науках, на что обратил внимание Ум. Эко: «В действительности мы редко даем определение сущности; гораздо чаще мы определяем вещи по их свойствам» [2, с. 254]. Такая ситуация способствует усилению гносеологического кризиса современной экономической науки. «В результате терминологической путаницы, отсутствия категориальной определенности, в последние десятилетия в мире наблюдается увеличение отрыва экономических практик от их теоретического осмысления» [50, с. 14].

Вместе с тем теоретические разработки постиндустриального общества Д. Белла обладают значительным гносеологическим потенциалом при описании и исследовании экономик стран второго типа. В настоящее время рядом ученых и политиков уже применяются понятия «сверхиндустриальная экономика» и «постиндустриальная экономика», как дополняющие друг друга как при описании разных моделей развития (онтологический подход), так и при описании различий национальных экономик (феноменологический подход). По нашему мнению, такое использование этих понятий будет способствовать дальнейшему прогрессу экономической науки.

Обособленно от социальной парадигмы постиндустриального общества и теоретических построений, выросших на ее основе (т. е. теоретических построений, основанных на технико-технологическом детерминизме), стоит политическая экономика знака Ж. Бодрийяра. Длительное время серьезной методологической ошибкой экономической науки являлось недостаточное внимание символическому потреблению и символическим потребностям, а это, применительно к теме нашего исследования, понятия ключевые, поэтому остановимся на этом подробно.

Ж. Бодрийяр справедливо замечал, что для дальнейшего прогресса современной политэкономии в частности и экономической науки в целом необходимо, чтобы «анализ различающей социальной функции предметов и анализ политической функции идеологии, которая с ней связана» [51, с. 12] исходил «из одной абсолютной предпосылки: из отмены само собой разумеющегося рассмотрения предметов в терминах потребностей, отмены гипотезы первичности потребительной стоимости» [51, с. 12]. Поясняя свою теоретическую позицию, вышеназванный автор справедливо отмечает, что эмпирическая гипотеза, господствующая сегодня как в экономическом мэйнстриме, так и в ортодоксальном марксизме, «поддерживаемая очевидностью обыденной жизни, приписывает предметам функциональный статус, статус утвари, связанный с техническими операциями, относящимися к миру, и даже - тем самым - статус опосредования антропологических "природных" потребностей индивида. В такой перспективе предметы в первую очередь зависят от потребностей, приобретая смысл в экономическом отношении человека к окружающей среде. Эта эмпиристская гипотеза неверна. Дело обстоит совсем не так, словно бы первичным статусом предмета был прагматический статус, на который лишь затем накладывалась бы социальная знаковая стоимость - наоборот, фундаментальным является знаковая меновая стоимость, так что потребительная стоимость подчас оказывается просто ее практическим приложением (или даже простой рационализацией): только в такой парадоксальной форме социологическая гипотеза оказывается верной» [51, с. 12]. В рамках такого подхода важнейшей функцией обмена благ и предметов становится институционализация социальной иерархии. 
Еще Т. Веблен показал, что даже если первоначальной функцией подчиненных классов являлось производство, то все равно одновременно они выполняют функцию утверждения статуса Хозяина. Более того, в ситуации, когда подчиненные классы содержатся в праздности, эта функция становится единственной [52]. В контексте нашего исследования наиболее важным является не сама социально-классовая дифференциация, хотя это тоже важно, а «рассогласование между подразумеваемой мобильностью (стремлениями) и реальной мобильностью (объективными шансами социального продвижения)» [51, с. 28]. Как отмечал по этому поводу Ж. Бодрийяр, «эти стремления (подразумеваемая мобильность - C. C.) не являются свободными <...> они зависят от социальной наследственности и от уже достигнутого положения. Дойдя до определенного порога мобильности, они вообще исчезают - такова абсолютная покорность. В общем, они относительно нереалистичны: мы надеемся на большее, чем объективно в состоянии достичь, и в то же самое время относительно реалистичны: мы не даем разыграться нашему излишне честолюбивому воображению» [51, с. 28].

Рассогласование между подразумеваемой и реальной мобильностями основывается на «неявной интерпретации социальными актантами объективных социологических данных: индустриальные общества предоставляют средним категориям населения определенные шансы на продвижение, но шансы сравнительно небольшие; социальная траектория за исключением отдельных случаев оказывается достаточно короткой, социальная инертность весьма ощутима, всегда остается возможность для регресса» [51, с. 29]. Ж. Бодрийяр писал, что в этом случае «создается впечатление, что: мотивация к восхождению по социальной лестнице выражает интериоризацию общих норм и схем общества постоянного роста; избыток стремлений по отношению к реальным возможностям выдает разбалансировку, глубокое противоречие общества, в котором "демократическая" идеология социального прогресса при случае вмешивается для того, чтобы компенсировать и переопределить относительную инертность социальных механизмов. Скажем иначе: индивиды надеются, потому что "знают", что могут надеяться, - они не надеются слишком, поскольку "знают", что это общество накладывает непроходимые препятствия на свободное восхождение, - и при этом они все-таки надеются чересчур, поскольку сами живут размытой идеологией мобильности и роста. Уровень их стремлений вытекает, следовательно, из компромисса между реализмом, питаемом фактами, и ирреализмом, поддерживаемым окружающей их идеологией - то есть из компромисса, который, в свою очередь, отражает внутреннее противоречие всего общества» [51, с. 29]. В результате возникает «противоречие между рациональной экономической логикой и культурной классовой логикой» [51, с. 44]. В данном случае Ж. Бодрийяр гениально раскрывает сущность современных развитых экономик, основанных на либерально-рыночной доктрине, подчеркивая, что по сравнению с индустриальными обществами роль идеологии начинает играть все большее и большее значение в хозяйственной жизни, именно экономическая идеология позволяет избегать серьезных социально-экономических конфликтов, делает латентными классовые противоречия, препятствует росту самосознания низших и средних классов, переводит политэкономическое противостояние на основе совпадения и противоречия классовых интересов в симуляцию политики.

Т. В. Сергиевич отмечает по этому поводу: «Современное общество < ..> особенно подвластно иллюзии социальной мобильности. Индикатором подразумеваемой социальной мобильности является уровень потребления благ» [53, с. 172]. Названный автор также отмечает, что «качественные преобразования в структуре производства в современной экономике во многом обусловлены ростом доли потребления знаковых благ. Классической сферой производства знаковых меновых стоимостей является производство товаров интенсивного обновления, где добавленная стоимость создается за счет 
управления механизмами социальной демонстрации» [54, с. 1]. Экономика знака проявляется и в том, что в современном обществе «мода используется индивидом в той степени и с той целью, насколько она способна отразить его принадлежность к определенному социальному классу или общественной группе, т. е. подчеркнуть его социальный статус <...> Такой переход (переход в более высший социальный класс - C. С.) может быть как реальным, так и иллюзорным. Под последним имеется в виду симуляция повышения социального статуса путем подражания индивидом представителям других классов, в первую очередь, в принципах поведения и потребления, представлениях (например, об искусстве, литературе и т. д.), предметном окружении (в первую очередь, формах одежды) и др., требующем минимум издержек. Реальная социальная мобильность особенно сложно достижима в современном обществе, разрыв между реальной и иллюзорной мобильностью увеличивается» [53, с. 171-172].

Очень откровенное и важное с точки зрения нашего исследования заявление по поводу европейских ценностей и проекта «Объединенная Европа» сделал Ж. Бодрийяр: «главной целью этой схемы интернациональной стратификации, проходящей под символом "Европы", является политическое осуществление национальной интеграции, свойственной каждой из рассматриваемых стран, причем осуществляется она не только со стороны потребления, но и со стороны стратификации» [51, с. 62]. При помощи этого проекта, позволяющего снизить степень накопления социального капитал и уровня самосознания низших классов «в статистической дихотомии, - отмечает Ж. Бодрийяр, снимается старое разнообразие противоборствующих классов: их по-прежнему два, но между ними больше нет конфликта - два термина меняются на два полюса "социальной динамики". Следствием (и целью) такого тактического разделения оказывается нейтрализация крайних элементов и, следовательно, всякого противоречия, которое могло бы возникнуть из них в социальном плане: существует один-единственный модельный уровень (направляющая схема) и - все остальные. Перемешанные статистикой, они представляются в качестве просто населения, огромного среднего класса или тех, кто им может стать, класса, культурно уже подготовленного к роскошествам привилегированных классов. Нет больше никакого радикального неравенства между главой предприятия и служащим низового звена, поскольку последний, смешавшись в статистике со средними классами, видит, что ему уже доверен "средний" standing и обещан standing высших классов. На всем протяжении социальной лестницы никто не подвергается окончательному исключению» [51, с. 62]. В Старой Европе, как отмечает Ж. Бодрийяр, «вокруг обладания культурными и материальными благами организуется целая новая концепция классовой стратегии. Ценности и критерии потребления подвергаются мнимой универсализации лишь затем, чтобы еще успешнее привязать "безответственные" классы (то есть не обладающие властью решения) к потреблению и, тем самым, сохранить для руководящих классов исключительность их власти» [51, с. 64]. Этот прием создает иллюзию объединения всех слоев «демократической» Европой.

Для этого нового общества характерно, помимо вышеназванных характеристик (изменение характера промышленного производства от массового изготовления до гибкого специализированного в ответ на технологические инновации; развитие сервисной экономики), формирование принципиально новых глобальных финансов, которые выходят за рамки своей традиционной функциональной роли в экономической системе общества и существуют достаточно изолированно от процессов, происходящих в реальном секторе экономики. Иллюстрируя этот разрыв, Ж. Бодрийяр в свое время писал: «Весьма любопытной чертой, связанной с крахом на Уолт-стрит в 1987 году, является неуверенность в том, имела ли на самом деле место настоящая катастрофа и ожидается ли таковая в будущем. Правильный ответ - нет, реальной катастрофы не будет, поскольку мы живем 
под знаком катастрофы виртуальной. В этом контексте красноречиво проявляется несоответствие между фиктивной экономикой и экономикой реальной. Именно этот диссонанс и защищает нас от реальной катастрофы производительной экономики» [1, с. 40]. Далее он добавляет, что «деньги вращаются в недоступном пространстве, которое оставляет мир таким, какой он есть. В конечном итоге, экономика продолжает производить, в то время как малейшего логического следствия из колебаний фиктивной экономики было бы достаточно, чтобы ее уничтожить (не забудем, что сегодня объем товарооборота в 45 раз уступает объему перелива капитала)» [1, с. 42]. Для современного общества также характерно возрастание роли общественно-функциональных инноваций. С расширением применения общественно-функциональных технологий для принуждения акторов к желательному для Манипулятора поведению посредством целенаправленной подачи информации в интернете и традиционных СМИ значительно искажается восприятие субъектами своих потребностей и интересов. «Любая коммуникация (в информащионном обществе C. C.), - пишет по этому поводу Ж. Бодрийяр, - по сути есть лишь принудительный сценарий, непрерывная фикция, избавляющая нас от пустоты нашего умственного экрана, на котором мы с не меньшим вожделением ждем изображения» [1, с. 22]. Кроме этого для общества, пришедшего на смену индустриальному, характерно изменение роли и функций информации в хозяйственной жизни в увеличении значения знаний для развития экономики. В современную эпоху информация, постоянно воспроизводящаяся и катастрофически разрастающаяся в интернете, приходит в свою противоположность. «Избыток знаний безразлично рассеивается по поверхности во всех направлениях, при этом происходит лишь замена одного слова другим» [1, с. 21]. Ж. Бодрийяр подчеркивает, что «написано и распространено столько знаков и сообщений, что они никогда не будут прочитаны. К счастью для нас! Ибо даже с той малой частью, которую мы абсорбируем, с нами происходит нечто, подобно казни на электрическом стуле» [1, с. 49]. В последнем случае речь идет по существу об использовании невероятно большого объема информационных сообщений не для получения или трансляции новых знаний, а как важного инструмента современных информационных войн. Причем последние сегодня ведутся не только между государствами и политическими партиями, но и между многочисленными классами и даже отдельными коммерческими организациями. Вместе с тем эта лавина интернет-информации слабо пересекается с теми знаниями, технологическими решениями, в которых сегодня как никогда нуждаются реальный сектор экономики и сфера услуг.

Но вернемся к гносеологической сути проблем современной экономики, раскрытых Ж. Бодрийяром. Названный автор писал о существовании трилогии развития ценностей: «начальная стадия, когда существовали повседневные, бытовые ценности; рыночная стадия, когда ценность выступает как средство обмена; структурная стадия, когда появляется ценность-символ. Закон естественного развития - закон рынка-структурный закон ценностей» [1, с. 10]. «После начальной, рыночной и структурной стадий ценности возникает стадия дробления, - поясняет Ж. Бодрийяр, - начальной стадии соответствует естественное природное состояние мира, и ценность развивалась согласно существовавшим естественным обычаям. Второй стадии соответствовала эквивалентность ценности, и ценность развивалась согласно логике торговли. На третьей стадии появился некий свод правил, и ценность развивается в соответствии с существующей совокупностью образов. На четвертой же стадии - стадии фрактальной, которую мы могли бы назвать также вирусной или стадией диффузии ценностей, уже не существует соответствия чему бы то ни было. Ценность распространяется во всех направлениях, без какой-либо логики, присутствуя в каждой скважине и щели. На этой стадии не существует более равноценности, присущей другим стадиям, нет больше самого закона ценности; есть лишь нечто, 
похожее на эпидемию ценности, на разрастание метастазов ценности, на ее распространение и рассеяние, зависящее лишь от воли случая. Строго говоря, здесь уже не следовало бы прибегать к самому понятию ценности, поскольку такое дробление, такая цепная реакция делает невозможным какое-либо исчисление и оценку» [1, с. 10-11]. После чего Ж. Бодрийяр констатирует: «Экономика, ставшая трансэкономикой, эстетика, ставшая трансэстетикой, сексуальность, ставшая транссэксуальностью, - все это сливается в универсальном поперечном процессе, где никакая речь не сможет более быть метафорой другой речи, потому что для существования метафоры необходимо существование дифференцированного поля и различных предметов. Но заражение всех дисциплин кладет конец такой возможности. Полная вирусная метонимия по определению (или, скорее по отсутствию определения)» [1, с. 14]. Очень гносеологически красивое определение, отражающее суть современного Западного общества, в этих условиях породившего социальную парадигму постиндустриальной экономики. Будь это философский текст, то на этом возможно можно было бы остановиться, но политико-экономическое определение современного общества, общества рисков, требует рассмотреть его экономическую онтологию.

\section{Современная экономика - экономика рисков}

Экономика рисков - это экономика высокотехнических и наукоемких производств, характеризующаяся высочайшей степенью политико-экономических, технологических, финансовых и экологических неопределенностей и рисков. В отличие от традиционных экономических рисков как возможности потерь хозяйствующими субъектами вследствие рыночной неопределенности или вмешательства государства в экономическую деятельность, являющихся атрибутивными признаками рыночной экономики, в современной экономике риски принимают всеобъемлющий характер, многие из них в принципе не предсказуемы - «черные лебеди», «эффект сверхуверенности» и т. д.

Нами уже неоднократно отмечалось, что «современная экономика перестает быть рыночной в понимании рынка первой половины XX века» [55, с. 23]. Радикальное изменение механизмов организации обмена между производителями и потребителями. Рыночный сегмент, длительное время господствующий в экономически развитых странах, становится периферийным. Для пострыночной экономики характерно наличие высокоэффективного промышленного производства, значительное увеличение доли сектора услуг в ВВП, дальнейшее увеличение значения знаний для развития экономики, развитие интернет-технологий и новые (пострыночные) формы конкурентной борьбы. Последние уже давно стали предметом изучения не только ученых экономистов, но и других обществоведов и гуманитариев. Так, например, Т. В. Солодовникова соглашается с тем, что «происходящая сегодня радикальная трансформация национальных экономик и мировой экономики в целом, сопровождающаяся формированием посткапиталистического общества, была вызвана технологической и информационной революциями. Активно развиваются принципиально новые формы конкуренции, в том числе направленные на нелетальное разрушение конкурентов (подрыв его имиджа, доверия к нему и т. д.)» [56, с. 44].

Собственно говоря, важным отличием рыночной экономики от пострыночной экономики и выступают новые общественно-функциональные технологии, применяемые в конкурентной борьбе. Прежде всего, это общественно-функциональные технологии (информационное оружие), направленные на нелетальное разрушение социальных субъектов и ориентированные на противодействие этому разрушению.

В настоящее время общественно-функциональные технологии, направленные на нелетальное разрушение социальных субъектов, из сферы военно-политического про- 
тивостояния естественным образом пришли в сферу политико-экономической конкуренции. В литературе все чаще и чаще стали встречаться новые понятия - «информационное оружие» и «информационная война», которые, в сущности, означают революцию не только в военном искусстве, но и в сфере компьютерно-информационных технологий. Часто за этим скрываются принципиально новые формы противоборства, в которых победа, «подавление противника» будет достигаться не с помощью классического (даже ядерного) оружия и традиционных способов ведения войны, а путем массированного использования информационного оружия. Многие аналитики технологических развитых стран считают этот вид оружия «решающим фактором владения современным миром». Национальные информационные ресурсы сегодня составляют все большую долю национального богатства в развитых странах. «Информационное оружие», сейчас называют «Троянским конем XXI века».

Появление информационного пространства привело к появлению желающих не только поделить это пространство, но и контролировать и управлять процессами, в нем происходящими. Для этого используется так называемое технико-ориентированное информационное оружие, которое подразделяется на то, которое направлено против компьютерных систем и способствует всяческой трансформации информации в пользу информационного агрессора. Оно выступает в таком случае в качестве средства уничтожения, искажения или хищения информации; средства преодоления систем защиты; средства ограничения допуска законных пользователей; средства дезорганизации работы технических средств, компьютерных систем. В отличие от технико-ориентированного информационного оружия, информационное оружие как общественно-функциональная инновация представляет собой такой вид информационного оружия, который подвергает воздействию определенные группы социальных субъектов с целью навязывания им нужного манипулятору социально-экономического поведения.

Возникновение кибернетического пространства ознаменовало собой начало эпохи информационных войн. Это можно объяснить тем, что с появлением все более и более усовершенствованных компьютерно-информационных технологий ведение информационной войны становится в разы быстрей и является более эффективным воздействием на социум. Так как хозяйствующий субъект уничтожается нелетально, а значит, победа в информационной войне является «алгоритмически неразрешимой проблемой». Самая главная задача применения информационного оружия состоит в том, чтобы заставить противника направить имеющиеся у него средства, в том числе технические, против самого себя. Информационное оружие второго типа направлено против социальных субъектов и включает в себя «не силовые» методы борьбы - такие, например, как сборку, так и разборку социального субъекта.

Для сборки и разборки социального (квази-социального) субъекта сегодня используется информационное оружие, под которым понимается средство ведения современной нелетальной войны. Оно обеспечивает идентификацию и поражение противника с помощью информационных концентраторов различных конструкций (традиционное СМИ, сетевые гипертекстовые концентраторы и т. п.). Позволяет оказать влияние на социальный субъект, приводящее к блокированию его социальных действий (социальной активности). Позволяет эффективно перераспределять (переделить) материальные ресурсы (изменить отношения собственности) без нанесения повреждений самой собственности. В результате чего «современная экономика становится критически зависимой от возможности определенными социально-экономическими субъектами (социальными группами) манипулировать поведением больших масс людей в своих эгоистических (эгональных - С. С.) интересах» $[57$, с. 126$]$. 
Если посмотреть на процессы сборки и разборки социального субъекта через призму категории экономика рисков, то становится очевидным, что в данном случае идет речь не только о нарушении рыночных принципов ценообразования, т. е. о значительном сокращении сферы применения закона спроса и предложения в хозяйственной практике, но и о нарушении законов образования и эволюции социальных классов, когда высшие классы могут навязывать средним и низшим классам свою идеологию, свою мораль, свои интересы. Иначе говоря, «класс в себе» не может стать «классом для себя» (К. Маркс), или в терминологии М. Вебера «класс» не может стать «социальным классом». А это значит, что классовая борьба, а ее никто не отменял, становится латентной и непредсказуемой [58]. В результате серьезно трансформируются социально-трудовые отношения и механизмы согласования экономических интересов, частично они становятся симулякрами, тем самым повышая непредсказуемость хозяйственной деятельности, порождают серьезные политико-экономические и технологические риски. Ж. Бодрийяр писал по этому поводу: «Традиционно инфляция и безработица составляют переменные, входящие в уравнение роста: на этом уровне кризиса нет - есть лишь неупорядоченные процессы, а сама неупорядоченность является тенью органической целостности. Ныне аномалия приобретает весьма тревожный характер. Она - не явный симптом, а странный знак упадка, нарушения правил какой-то тайной игры или, по меньшей мере, чего-либо, нам неизвестного [1, с. 50]». Далее он приводит еще один пример: «И безработица тоже изменила смысл. Это уже не стратегия капитала (резервная армия), не критический фактор в игре социальных отношений. Иначе, при том, что напряженность уже превзошла все пределы, безработица привела бы к неслыханным потрясениям [1, с. 51]». Отсутствие четких правил игры в социально-классовых отношениях, поскольку у подавляющего большинства социально-классовых образований современного общества отсутствует «классовое» сознание, привело сегодня к росту популистских партий. Эти партии ориентируются не на объективные политико-экономические интересы, а на потребностные ожидания, что само по себе усиливает неопределенность и риски в экономической политике.

Значительный вклад в превращение традиционной капиталистической экономики в экономику рисков принадлежит глобальным спекулятивным финансам. То, что в последние двадцать лет значительно повысилась неустойчивость мировой экономики, прежде всего, связано с изменением в ней роли и функций финансов, а также значительным усилением глобальной финансовой неустойчивости. Причем в основе последней лежит «изменение природы и роли финансов: из обеспечивающих и обслуживающих экономику они стали доминирующими над экономикой, - отмечает М. А. Сажина. - Более того, работая преимущественно на себя, они действуют глобально. Оторванные от своего материального носителя, глобальные виртуальные финансы постоянно движутся, причем с очень высокой скоростью: за секунду миллиарды долларов, а за день триллионы долларов могут сменить своих собственников. В результате для виртуальных денег характерна постоянная смена субъекта собственности и размытость диффузия прав собственности. В следствие этого они потеряли такую характерную черту, как управляемость, выключились из процесса рыночного саморегулирования, усилили риски и придали экономике черты нестабильности» [59, с. 32]. Современные глобальные финансы значительно нарушают действие рыночных законов в планетарном масштабе. Причем это нарушение намного больше, чем то нарушение, которое наблюдалось в период после Второй мировой войны от хозяйственной деятельности всех социалистических стран. Ж. Бодрийяр писал по этому поводу: «есть нечто другое, гораздо более ошеломляющее чем инфляция. Это - оборот денежной массы, охватывающий Землю своей круговой орбитой» $[1$, с. 50]. Гносеологическое осмысление новой роли финансов во многом затруднено (помимо того, что современные глобальные финансы - это принципиально новое явления в экономической истории) еще 
и тем, что на региональном и страновом уровне финансы в ряде случаев продолжают выполнять свои традиционные функции.

Результатом деятельности глобальных финансов в условиях отсутствия действенных межстрановых институционально-финансовых фильтров (барьеров), защищающих национальные экономики от спекулятивных атак глобальной финансовой системы могут очень быстро разрушить национальный промышленный комплекс, сельское хозяйство и в целом сложившийся в данной стране уклад хозяйственной жизни. При этом «нарушаются не только сложившиеся макроэкономические пропорции, но и возникают новые диспропорции. Среди них: разрыв между инвестициями и сбережениями, появились страны с хроническим дефицитом и хроническим профицитом текущих статей платежного баланса, растет задолженность, учащаются и усиливаются финансовые кризисы» [59, с. 32]. При этом основой глобальной финансовой неустойчивости является долларизация мировой экономики. В период золотого обеспечения доллара как основной резервной валюты это во много отражало политико-экономические реалии второй половины сороковых начала семидесятых годов прошлого века, когда сразу после Второй мировой войны США производили 56 \% мирового промышленного и сельскохозяйственного производства и обладали примерно 70 \% мирового запаса золота.

После отказа от золотого обеспечения доллара США получили возможность «проводить фактически ничем не ограниченную эмиссию доллара, стимулировать внутренний спрос в стране, не обеспечивая его реальным ростом экономики. В конечном счете это привело к чрезмерному увеличению денежной массы резервной валюты и к снижению ее эффективности. В результате США сняли с себя и со своих банков всякие обязательства за эмитируемые ими доллары» [59, с. 32]. Как результат, чтобы уменьшить свои финансовые риски все страны - владельцы долларовых валютных резервов, помещали их на счета американских банков, а у последних возникла проблема как размещать эти лишние доллары, которые изначально не были востребованы американским рынком. «Банки пустились финансировать "пузыри" на фондовом рынке, раздавать дешевые ипотечные кредиты практически без всякого контроля за заемщиками, осуществлять льготное кредитование диктаторских режимов в мире. Но самое негативное следствие этих действий состоит в том, - справедливо отмечает М. А. Сажина, - что американские финансовые институты стали формировать международные "горячие деньги", которые начали кочевать по фондовым и валютным рынкам разных стран, усиливая их цикличность, ввергая в постоянные подъемы и кризисы» [59, с. 32]. Эти «горячие деньги» в основе относятся к фиктивному капиталу, который работает на воспроизводство самого себя, опровергая самим своим существованием и теорию стоимости, и закон спроса и предложения и многое другое. Ж. Бодрийяр в свое время справедливо утверждал, что «надежда примирить фиктивную экономику с реальной утопична: эта свободно обращающиеся миллиарды долларов невозможно переместить в реальную экономику, что, впрочем, является большой удачей, ибо если бы каким-то чудом они оказались вложены в производство, это стало бы настоящей катастрофой» [1, с. 43]. Проблема глобальных финансов не может быть раскрыта в рамках одной статьи, да это и не является нашей задачей. Исходя из цели нашего исследования, нам в данном случае важно, что эти глобальные спекулятивные финансы вносят свой значительный «вклад» в возникновение и эволюцию экономики рисков.

Еще одной важной причиной возникновения и сохранения экономики рисков выступает очень высокая неопределенность технико-технологических прогнозов. В результате возникает множество дополнительных рисков на уровне государства и коммерческих организаций, вызванных этой неопределенностью. Рассмотрим это подробнее. 
Современная структурная политика в контексте технологической модернизации экономики должна исходить, как справедливо подчеркивают С. Губанов [60], Д. Фролов, И. Полынцев [61, с. 27], из реалистичного системного анализа тенденций развития современных индустрий. «Особенно это касается наиболее динамично развивающихся высокотехнологичных индустрий, обладающих потенциалом утверждения в качестве "ядра" неоиндустриального хозяйства» [61, с. 27]. Для успешной реализации современной структурной политики необходимо наличие и оптимальное сочетание таких важнейших экономических ресурсов как: человеческий капитал; социальный капитал; финансовый капитал и материально-вещественный капитал. Все названные формы капитала одинаково важны для проведения новой индустриализации, но в различные периоды может наблюдаться нехватка (дефицит) какого-либо из них. Соответственно, и экономическая эффективность добавления этого фактора будет возрастать. При этом в ряде случае несколько из названных видов капитала могут одновременно существовать в рамках одной бытийной формы (одного социально-экономического явления). Например, социальноэкономическое сообщество является одновременно формой расширенного воспроизводства человеческого и социального капиталов.

Современная структурная политика формируется в условиях глубокого кризиса наноиндустрии [61]. Д. Фролов и И. Полынцев подчеркивают, что «осмысление причин и последствий кризиса наноиндустрии позволит конструктивно скорректировать стратегию ее развития и политику регулирования» [61, с. 27], что позволит скорректировать структурную политику и оптимизировать использование бюджетных ресурсов, направляемых на НИОКР.

Напомним, что «импульсом глобального развития наноиндустрии стало утверждение и начале 2000 г. президентом США Б. Клинтоном первой в мире государственной стратегии в области нанотехнологий - национальной нанотехнологической инициативы» [61, с. 27]. США направили колоссальные ресурсы на финансирование этой стратегии, которые к 2017 г. составили более 24 млрд долл. США [62, p. 25]. В национальной нанотехнологической инициативе «был озвучен прогноз объема мирового рынка продукции наноиндустрии - 1 трлн. долл. к 2015 г. Главным эффектом перспективы «триллионного рынка» для нанотехнологий стала боязнь правительств во всем мире пропустить новую технологическую революцию и дать США возможность глобального доминирования в сфере инноваций. Этого было достаточно, чтобы породить сначала в развитых, а затем и развивающихся странах множество стратегических действий по развитию нанотехнологий» [61, с. 27]. В результате «в мире начинается научное соревнование за достижение передовых позиций в нанотехнологиях. Остроту ситуации характеризует стремление США не просто лидировать, а доминировать на этом направлении науки» [63, с. 2]. Д. Фролов и И. Полынцев отмечают, что в результате этого «в большинстве стран были приняты стратегии и программы развития нанотехнологий по аналогии с ННИ (нащиональной нанотехнологической инициативой - С.С.). В результате совокупный объем государственных и частных инвестиций в связанные с нанотехнологиями и наноматериалами исследования и разработки неуклонно увеличивался. Так, в период 1997-2004 гг. данный показатель вырос в 20 раз - с 0,4 до 8,6 млрд долл.» [61, с. 27]. Названные авторы для характеристики этой ситуации приводят в своей работе высказывание американских ученых [64; 65], о том, что «К середине 2000-х гг. конкуренцию стран в сфере наноиндустрии с полным основанием можно было охарактеризовать как "наногонку", сравнимую с "лунной гонкой" 1960-х гг. и представляющую собой превращенную форму "гонки вооружений" в мирное время» [61, с. 27]. За десять лет после принятия национальной нанотехнологической инициативы правительства во всем мире инвестировали в нанотехнологии свыше 65 млрд долл. [61, с. 28]. «В 2010 г. инвестиции частных компаний впервые превысили 
вложения со стороны государств: если в 2009 г. корпорации и правительства во всем мире инвестировали в наноиндустрию по 8,4 млрд долл., то в 2010 г. частный бизнес вложил уже 9 млрд долл., а государственные расходы составили 8,2 млрд долл. По состоянию на 2010 г. лидерами корпоративных инвестиций в сферу нанотехнологий выступали США, Япония и Германия, при этом Россия заняла последнее место в данном рейтинге» [61, с. 28].

На этом фоне возникают сверхоптимистичные прогнозы объемов рынка наноиндустрии «в триллионном измерении, от 1 до 4,4 трлн. долл. (Lux Research, National Scientific Foundation, Cientifica, RNCOS)» [61, с. 28], умеренно-оптимистичные прогнозы исчисляют объем рассматриваемого рынка в сотнях миллиардов долларов, от 148 до 750 млрд долл. (European Commission, Wintergreen, MRI, Evolution Capital) и пессимистичные (или реалистичные по определению BCC Research) прогнозы измеряют объем данного рынка десятками миллиардов долларов, от 64,2 до 75,8 млрд долл. (BCC Research, Research and Markets)» [61, c. 28-29].

Д. Фролов и И. Полынцев объясняют такой широкий разброс оценок тем, что: вопервых, «речь идет о рынке быстро развивающейся технологии широкого применения, потенциал которой фактически еще не раскрыт окончательно даже на уровне фундаментальных исследований» [61, с. 29], во-вторых, «в оптимистичных прогнозах учитывается совокупная стоимость продукции, произведенной с применением нанотехнологий и наноматериалов, а не стоимость самих нанотехнологий и наноматериалов, что приводит к завышенным оценкам рынка» [61, с. 29], в-третьих, увлечением многих ученых «построением описательных моделей будущей экономики, основанной на нанотехнологическом укладе, тяготеющих к утопическим или апокалиптическим сценариям. Например, по мнению некоторых исследователей, развитие VI технологического уклада, базирующегося на нанотехнологиях (по классификации С. Глазьева), приведет к возникновению эффекта экономической сингулярности, вследствие которой нанотехнологии проникнут во все виды технологий и фактически поглотят их, а наноиндустрия включит в себя все ранее известные индустрии» [61, с. 30].

М. Кастельс в свое время предупреждал об опасности субъективных завышенных оценок развития новейших комплексных технологий, подчеркивая при этом: «Существенно, таким образом, сохранять дистанцию между оценкой возникновения новых социальных форм и процессов, индуцированных и допускаемых новыми технологиями, и экстраполяцией потенциальных последствий таких событий для общества и людей: только конкретный анализ и эмпирические наблюдения смогут определить исход взаимодействия между новыми технологиями и возникающими социальными формами» [66, с 78]. Используя эту идею М. Кастельса применительно к развитию наноиндустрии, Д. Фролов и И. Полынцев отмечают: «Как утопические, так и алармистские сценарии развития наноиндустрии достаточно быстро оказались опровергнуты объективной реальностью» [61, с. 30]. Сегодня «сверхоптимистичные ожидания инвесторов (по поводу развития наноиндустрии $-C$. C.) по большому счету не оправдались: индексы нанотехнологических компаний отстают от обычных фондовых индексов, ушла в прошлое мода на добавление приставки "нано" в названия стартапов, интерес общества к нанотехнологиям резко упал, а результатами исследований и разработок в области нанонауки и наноинженерии активно пользуются корпорации, не позиционирующиеся в качестве представителей наноиндустрии <...> По сути, нанотехнологии как радикальная инновация выразились в многочисленных улучшающих изменениях в уже сложившихся отраслях экономики» [61, с. 30-31]. «Снижение инвестиционной привлекательности наноиндустрии, подчеркивают Д. Фролов и И. Полынцев, - видно по динамике специализированных бир- 
жевых индексов» [61, с. 31]. Эти авторы также добавляют, что «многие предприятия наноиндустрии, вышедшие на фондовый рынок в начале и середине 2000-х гг., снизили свою капитализацию в десятки раз» [61, с. 32].

Все это требует в структурной политике отказаться от адресной специализированной модели наноиндустрии и перейти к «зонтичным стратегиям развития наноиндустрии в составе комплексных технологических направлений, например развивающихся (emerging) технологий или STI (наука, технологии и инновации; от англ. Science, Technology and Innovation), а также к секторно и проблемно ориентированным стратегиям развития нанотехнологий в рамках более широких стратегий устойчивого роста или развития промышленности» [61, с. 33]. По нашему мнению, следует согласиться с Д. Фроловым и И. Полынцевым о том, что предположение о том, что ядром нового технологического уклада станут нанотехнологии не оправдалось [67; 68; 69]. «Вопреки подавляющему большинству прогнозов, нанотехнологии не поглотили все остальные быстро развивающиеся технологии, а, по сути, "растворились" в них. Наноиндустрия не стала "ядром" нового уклада и де-факто не сложилась как отдельная индустрия. Хотя наноиндустрия не относится к так называемым быстро развивающимся индустриям (emerging industries), таким как большие данные (big data), биофармацевтика, мобильные технологии и др., анализ показывает, что нанотехнологии тесно связаны с этими индустриями и выступают для них обеспечивающей, инфраструктурной технологией» [70, с. 35-36].

Во многом в результате идеологического влияния социальной парадигмы постиндустриального общества в экономической науке до настоящего времени отсутствуют четкие фундаментальные теоретические представления о том, что же следует понимать под технологической эволюцией. В российской научной литературе эта гносеологическая проблема описывается так: «Известна идея - представить, технологическую эволюцию как смену неких технико-экономических парадигм (К. Перес), в российской более поздней версии - так называемых технологических укладов. Эти вещи ретроспективные, классификационные, это абстрактные схемы, ничего не проясняющие в технологическом развитии, поскольку никто ничего не может сказать о шестом (иногда и о пятом!), не говоря уже о седьмом или восьмом укладе (парадигме). Следовательно, пока точно не установлено, что составляет его основу (уклада), правдоподобно сказать о нем затруднительно, по крайней мере, на коротком отрезке времени. Только обернувшись назад, можно сказать о прошлых этапах, условно подразделяя их на некоторые периоды времени» [71, с. 12-13]. Иначе говоря, достаточно популярная сегодня концепция смены технологических укладов представляет собой ретроспективную концепт схему.

Однако этой идее придается вес не только как ретроспективной концепции-схеме [71, с. 12-13], а как основе для текущей экономической политики. Так, например, в работе «Нанотехнологии как ключевой фактор нового технологического уклада в экономике» [67], вышедшей в 2009 г., отмечается, что «всплеск и падение цен на энергоносители, мировой финансовый кризис - верные признаки завершающей фазы жизненного цикла доминирующего технологического уклада и начало структурной перестройки экономики на основе следующего уклада» [67, с. 17]. Оставляю в стороне вопрос, почему во время множества других мировых экономических кризисов, регулярно повторяющихся во второй половине XX, начале XXI веков и не редко сопровождаемых всплеском и падением цен на энергоносители (например, мировой кризис 1974-75 гг.) - это не свидетельствовало о смене доминирующих технологических укладов, отметим только, что социальная парадигма смены технологических укладов категориально не описана. О. А. Наумович отмечает по этому поводу: «Однако, отсутствие стройных (внутренне непротиворечивых) понятийных рядов негативно сказывается в том плане, что любое, 
даже самое точное и совершенное определение (если оно не вписано адекватным образом в понятийный ряд, т. е. систему других взаимосвязанных понятий и категорий) не позволяет содержательно решить сложную многоуровневую задачу, не только раскрыть сущность того или иного технологического уклада как социально-экономического феномена, но и как определенной стадии развития человеческого общества, определенного этапа в развитии экономики, определенного этапа в развитии самого общества, жизни людей, политэкономически как феномена, но и одновременно раскрыть те факторы или сущность, почему оно возникло, т. е. его генезис» [72, с. 35]. Сложившая в экономической науке постсоветских стран после 1991 г. ситуация отказа многими учеными-экономистами, работающими в конкретно-экономических направлениях, характеризующаяся отказом от теоретико-методологической проработки принципов своих исследований, создала условия для слепого копирования технологической политики западных стран. Например, если западные страны активно развивают наноиндустрию, то и мы будем поступать так же. Ошибочность такого подхода нами была описана выше.

При этом в структурном и технологическом планировании «нужно учитывать текущее состояние базовых технологий» [71, с. 13], поскольку в ситуации резкого отставания от сверхиндустриальных стран базисных машиностроительных технологий, инженерной работы и оказания услуг промышленного характера [44], «никакие рецепты вложений в нанотехнологии не только нельзя назвать обоснованными, но они порождают дополнительные структурные перекосы и не являются отражением той системности действий и развития общих технологий, которые могут потребовать на следующем этапе и нанотехнологий, как неотъемлемого элемента в некотором объеме, который будет задан масштабом и потребностями экономики, ее общей технологичностью» [71, с. 13]. Соглашаясь с этими высказываниями, вместе с тем следует подчеркнуть, что вышеназванные проблемы не могут быть преодолены без теоретического осмысления взаимозависимости экономики рисков технологической неопределенности.

\section{ВЫВОДЫ}

В 1960-90-х годах прошлого века в странах золотого миллиарда сформировался новый тип обывателя, обывателя сытого и самодовольного, который в период этих благодатных пятидесяти лет (европейского «золотого века»), когда финансовые и политические элиты капиталистических стран были вынуждены, борясь с социалистической идеей, делиться частью своих сверхприбылей со своими согражданами. В результате новый европейский обыватель, вооруженный идеями протестантского фундаментализма и «общечеловеческими» ценностями, не заметил, что социальные лифты в ЕС давно перестали работать, а децильные коэффициенты достигли заоблачных высот, по сравнению с которыми имущественная дифференциация в Римской империи кажется образцом социальной справедливости. Децильный коэффициент в Великобритании сегодня равняется 100! Золотой век в Западной Европе закончился, закончился в ней и период латентных экономических конфликтов. Общественные науки и, в том числе, теоретическая экономика, занятые выполнением социального заказа высших социальных классов (всеми способами поддерживать и совершенствовать либерально-рыночную идеологию, основанную на идеях протестантского фундаментализма), не заметили радикальных политико-экономических изменений - возникновение и быстрое развитие экономики рисков. Повторилась ситуация 1929 г., когда большинство западных ученых экономистов «просмотрели» качественные изменения в капиталистической экономике, приведшие к страшному мировому экономическому кризису. И тогда, и сейчас причиной этому стала их идеологическая зашоренность. 
Экономика рисков - это экономика высокотехнических и наукоемких производств, характеризующаяся высочайшей степенью политико-экономических, технологических, финансовых и экологических неопределенностей и рисков. Эти риски принимают всеобъемлющий характер, многие из них в принципе не предсказуемы и их возможные негативные последствия могут привести Человечество к глобальной катастрофе.

Понять природу экономики рисков - значит научиться им противостоять. Без обновления методологии политической экономии это будет невозможно.

\section{СПИСОК ИСПОЛЬЗОВАННЫХ ИСТОЧНИКОВ}

1. Бодрийяр, Ж. Прозрачность зла / Ж. Бодрийяр ; Пер. с фр. Л. Любарской, Е. Марковской. . - 5-е изд. - М.: «Добросвет», «Издательство "КДУ"», 2014. - 260 с.

2. Эко, Ум. Откровения молодого романиста / Ум. Эко. - М.: АСТ; Corpus. 2013. $-320 \mathrm{c}$.

3. Струве, П. Б. Первичность и своеобразие обмена и проблема «равновесия». Ответ А. Д. Билимовичу / П. Б. Струве // Экономический Вестник. - 1924. - Кн. 3 (1) - С. 33-50.

4. Современные глобальные трансформации и проблема исторического самоопределения восточнославянских народов: моногр. / Ч. С. Кирвель [и др.]; под науч. ред. Ч. С. Кирвеля. - 2-е изд., перераб. и доп. - Гродно: ГрГУ, 2009. - 547 с.

5. Кейнс, Дж. Общая теория занятости, процента и денег [Электронный ресурс] / Дж. Кейнс // Учебники, монографии по социологии. - Режим доступа: http://socioline.ru/ files/5/316/keyns.pdf. - Дата доступа: 23.08.2016.

6. Солодовников, С. Ю. Культ карго, или Новый объект экономической науки / С. Ю. Солодовников // Белорусская думка. - 2016. - № 1. - С. 56-62.

7. Борисов, Б. Голодомор по-американски / Б. Борисов [Электронный ресурс] // Око планеты. Новости, аналитика, информация. - Режим доступа: http://oko-planet.su/first/ 4702-boris-borisov-golodomor-po-amerikanski.html. - Дата доступа: 14.09.2016.

8. Чуньков, Ю. И. Взаимодействие объективного и субъективного в социалистической экономике : (Политэкономический аспект исследования) / Ю. И. Чуньков. Томск: Изд-во Томского ун-та, 1984. - 193 с.

9. Ансар, П. Современная социология / П. Ансар // Социологические исследования. - 1996. - № 1. - С. 134-150.

10. Радаев, В. В. Социология рынков: к формированию нового направления / В. В. Радаев. - М.: ГУ ВШЭ, 2003. - 328 с.

11. Ипполитов, Л. Зарождение институционалистской экономической теории в России (об одной методологической дискуссии 1920-х годов / Л. Ипполитов // Вестник Института экономики Российской академии наук. - 2008. - № 4. - С. 43-57.

12. Булгаков, С. Н. Философия хозяйства / С. Н. Булгаков / Отв. ред. О. Платонов. - М.: Институт русской цивилизации, 2009. - 464 с.

13. Туган-Барановский, М. И. Социальная теория распределения / М. И. ТуганБарановский // Известия С.-Петербургского политического института, отдел наук экономических и исторических. - 1913. - Т. 20. - С. 1-20

14. Струве, П. Хозяйство и цена. Критические исследования по теории и истории хозяйственной жизни. Ч. 1 / П. Струве. - СПб.; М., 1913. - 358 с.

15. Мировая экономическая мысль. Сквозь призму веков. В 5 т. - Т. III. Эпоха социальных переломов / Отв. ред. А. Г. Худокормов. - М., 2005. - 893 с.

16. Струве, П. Б. Научная картина экономического мира и понятие «равновесия»/ П. Б. Струве // Экономический Вестник. - 1923. - Кн. 1. - С. 5-26. 
17. Радаев, В. В. К обоснованию модели поведения человека в социологии (основы «экономического империализма») / В. В. Радаев // Социологические чтения. Вып. 2. М.: Институт «Открытое общество»: Институт социологии РАН, 1997. - С. 177-189.

18. Радаев, В. В. Рынок как объект социологического исследования / В. В. Радаев // Социологические исследования. - 1999. - № 3. - С. 28-37.

19. Becker, G. Nobel Lecture: The Economic Way of Looking at Behavior / G. Becker // Journal of Political Economy. - 1993. - Vol. 101. - P. 385-409.

20. Беккер, Г. Выбор партнера на брачных рынках / Г. Беккер // THESIS. - 1994. Вып. 6. - С. 12-36.

21. Шульц, Т. Ценность детей / Т. Шульц // THESIS. - 1994. - Вып. 6. - С. 37-49.

22. Бьюкенен, Дж. М. Сочинения / Дж. М. Бьюкенен. - Т. 1. - М.: Таурус-Альфа, 1997. - $556 \mathrm{c}$.

23. Block, F. The Role of the State in the Economy / N. Smelser, R. Swedberg (eds.). // The Handbook of Economic Sociology. - Princeton: Princeton University Press, 1994. - P. 206-232.

24. Evans, P. B. Embedded Autonomy / P. B. Evans. - Berkeley: University of California Press, 1995.

25. Frye, T. The Invisible Hand and the Grabbing Hand / T. Frye, A. Schleifer // American Economic Review. Papers and Proceedings. - 1997. - Vol. 87. - № 2. - P. 354-358.

26. Shleifer, A. The Grabbing Hand: Government Pathologies and Their Cures / A. Schleifer, R. Vishny. - Cambridge: Harvard University Press, 1998. - 278 p.

27. Bell, D. The Coming of Post-Industrial Society: A Venture in Social Forecasting / D. Bell. - New York: Basic Books, 1973. - 507 p.

28. Вередюк, О. В. Детерминанты занятости в концепции постиндустриального общества / О. В. Вередюк // Вестник СПбГУ. Сер 5. - 2010. - Вып. 4. - С. 35-41.

29. Machlup, F. The Production and Distribution of Knowledge in the United States / F. Machlup. - Princeton University Press, 1962. - 523 p.

30. The Knowledge Society / Ed. by G. Bohme \& N. Stehr. D. - Reidel Publishing Company, Holland, 1984. - 209 p.

31. Brzezinski, Z. Between Two Ages: America's Role in the Technetronic Era / Z. Brzezinski. - New York: The Viking Press, 1970. - 355 p.

32. Castells, M. The Information Age: Economy, Society and Culture / M. Castells // The Rise of the Network Society. - London and Oxford: Blackwell Publisher, 1996. - Vol. I. P. 151-200.

33. Roszak, T. Where the Wasteland Ends: Politics and Transcendence in Postindustrial Society / T. Roszak. - Garden City; New York: Doubleday \& Company, 1972. - 492 p.

34. Иноземцев, В. Л. За пределами экономического общества / В. Л. Иноземцев. М.: Academia. - Наука, 1998. - 640 с

35. Castells, M. The Rise of the Network Society: 2nd ed. / M. Castells. - Wiley-Blackwell, 2010. $-597 \mathrm{p}$.

36. Toffler, A. Creating a New Civilization. The Politics of the Third Wave / A. Toffler, H. Toffler. - Turner Publishing, Atlanta, 1993. [Electronic resource]. - Mode of access : http://www.archipelag.ru/autors/toffler. - Date of access : 17.10.2010.

37. Солодовников, С. Ю. Социально-экономические факторы, определяющие изменение системы трудовой мотивации в новых социально-экономических и технологических условиях в Беларуси / С. Ю. Солодовников // Экономическая наука сегодня : сб. науч. ст. / БНТУ. - Минск, 2017. - Вып. 5. - С. 296-308.

38. Солодовников, С. Ю. Социальный капитал как экономический ресурс / C. Ю. Солодовников // Вестник Полоцкого государственного университета. Серия D, Экономические и юридические науки. - 2015. - № 5. - С. 2-9. 
39. Солодовников, С. Ю. Цивилизация, культура, институциональные матрицы и экономическая система общества: феноменологическая природа, взаимообусловленность, социальный генезис / С. Ю. Солодовников // Вопросы сервиса и экономики. 2012. - № 4. - C. 5-22.

40. Deutschlands Zukunft als Produktionsstandort sichern. Umsetzungsempfehlungen für das Zukunftsprojekt Industrie 4.0. Abschlussbericht des Arbeitskreises Industrie 4.0 [Elektronische Quelle] / Promotorengruppe Kommunikation der Forschungsunion Wirtschaft - Wissenschaft // Bundesministerium für Bildung und Forschung. - 116 s. - Zugriffsmodus: https:// www.bmbf.de/files/Umsetzungsempfehlungen_Industrie4_0.pdf. - Zugriffsdatum: 08.08.2018.

41. Мелешко, Ю. В. Системообразующие принципы развития услуг промышленного характера / Ю. В. Мелешко // Устойчивое развитие экономики: состояние, проблемы, перспективы: сборник трудов XI международной научно-практической конференции. - 2017. - С. 84-86.

42. Мелешко, Ю. В. Оценка эффективности развития услуг промышленного характера в контексте модернизации национального промышленного комплекса / Ю. В. Мелешко // Вестник Коми республиканской академии государственной службы и управления. Серия: Теория и практика управления. - 2017. - № 18 (23). - С. 39-47.

43. Мелешко, Ю. В. Эволюция услуг промышленного характера в Республике Беларусь в 1995-2015 гг. / Ю. В. Мелешко // Экономическая наука сегодня : сб. науч. ст. / БНТУ. - Минск, 2017. - № 5. - С. 127-144.

44. Мелешко, Ю. В. Значение услуг промышленного характера в повышении конкурентоспособности промышленных предприятий (в контексте четвертой промышленной революции) / Ю. В. Мелешко // Экономическая наука сегодня : сб. науч. ст. / БНТУ. Минск, 2017. - № 6. - С. 64-78.

45. Сергиевич, Т. В. Труд в неоиндустриальном обществе / Т. В. Сергиевич // Научно-образовательный центр «Технологии товароведческой, таможенной и криминалистической экспертизы» Сборник научных работ № 6. Под редакцией Г. Д. Дроздова. СПб.: Изд-во СПбГЭУ, 2015. - С. 50-55.

46. Солодовников, С. Ю. Тенденции и перспективы развития занятости и создания социально-научного сообщества в условиях модернизации транзитивной экономики: на примере Республики Беларусь / С. Ю. Солодовников // Вестник Полоцкого государственного университета. Серия D, Экономические и юридические науки. - 2015. - № 6. - С. 2-9.

47. Мелешко, Ю. В. Методическое обеспечение совершенствования экономического механизма оказания услуг промышленного характера / Ю. В. Мелешко // Вестник Полоцкого государственного университета. Серия D: Экономические и юридические науки. - Минск, 2016. - № 14. - С. 51-60.

48. Мелешко, Ю. В. Основные формы сотрудничества предприятий реального сектора экономики Республики Беларусь и Российской Федерации в сфере производства космической техники / Ю. В. Мелешко // Право. Экономика. Психология. - 2018. № 1 (9). - С. 37-42.

49. Солодовников, С. Ю. Гносеологические трудности при изучении классов в постиндустриальном обществе / С. Ю. Солодовников // Социологический альманах. 2012 - № 3. - С. 74-91.

50. Солодовников, С. Ю. Теоретико-методологические основы исследования взаимосвязи теории трудовой мотивации и динамики трудовых отношений / С. Ю. Солодовников, Т. В. Сергиевич // Вестник Полоцкого государственного университета. Серия D, Экономические и юридические науки. - 2016. - № 5. - С. 12-16.

51. Бодрийяр, Ж. К критике политической экономии знака / Ж. Бодрийяр / пер. с фр. Д. Кралечкин. - М. : Академический Проект, 2007. - 335 с. 
52. Veblen, Th. The Theory of the Leisure Class / Th. Veblen. - 1899, фр. пер.: La Theorie de la classe de loisir; Paris, Gallimard, 1969.

53. Сергиевич, Т. В. Мода как объект экономического исследования / Т. В. Сергиевич // Бизнес. Инновации. Экономика : сб. научн. ст. / Институт бизнеса и менеджмента технологий БГУ; редкол.: В. В. Апанасович (председатель). - Минск: Печатный Дом «Вишневка», 2017. - Вып. 1. - С. 170-179.

54. Сергиевич, Т. В. Совершенствование организационно-экономического механизма производства товаров интенсивного обновления : автореф. дис. ... канд. экон. наук : 08.00.05 / Т. В. Сергиевич ; БГУ. - Минск, 2018. - 30 с.

55. Солодовников, С. Ю. Феноменологическая природа взаимообусловленности экономической конкурентоспособности и социального капитала Беларуси и Украины / С. Ю. Солодовников // Экономическая наука сегодня : сб. науч. ст. / БНТУ. - Минск, 2015. - Вып. 3. - С. 23-34.

56. Солодовникова, Т. В. Инструменты подмены оснований в современном экономическом дискурсе / Т. В. Солодовникова // Право. Экономика. Психология. -2018 . - № 1 (9). - С. 43-48.

57. Солодовникова, Т. В. Ложная аргументация как инструмент экономического дискурса / Т. В. Солодовникова // Экономические исследования и разработки: научноисследовательский журнал. - Нижний Новгород: НОО «Профессиональная наука». 2017. - № 2. - С. 125-143.

58. Солодовников, С. Ю. Классы и классовая борьба в постиндустриальном обществе: методологические основы политико-экономического исследования / С. Ю. Солодовников. - Минск : БНТУ, 2014. - 378 с.

59. Сажина, М. А. Природа современных финансов / М. А. Сажина // Экономические науки. - 2014. - № 9. - С. 25-33.

60. Губанов, С. Об экономической модели и долгосрочной стратегии новой индустриализации России / С. Губанов // Экономист. - 2016. - № 2 - С. 3-10.

61. Фролов, Д. Кризис наноиндустрии и ее будущее / Д. Фролов, И. Полынцев // Экономист. - 2017. - № 5 - С. 27-37.

62. The National Nanotechnology Initiative Supplement to the President's 2017 Budget // National Science and Technology Council. - 2016. - 104 p.

63. Арский, Ю. М. От редакционной коллегии / Ю. М. Арский // Индустрия наносистем и наноматериалов. - 2007. - № 1.

64. Hullman, A. Who is winning the global nanorace? / A. Hullman // Nature Nanotechnology. - 2006. - № 1. - P. 81-83.

65. Nanomanufacturing: Emergence and Implications for U. S. Competitiveness, the Environment, and Human Health. Report to Congressional Requesters // United States Government Accounability Office. - 2014. - P. 22.

66. Кастельс, М. Информационная эпоха: экономика, общество и культура / М. Кастельс. - М.: ГУ ВШЭ. - 2000. - 608 с.

67. Нанотехнологии как ключевой фактор нового технологического уклада в экономике» / С. Ю. Глазьев [и др] ; под ред. С. Ю. Глазьева, В. В. Харитонова. - М.: Тровант, 2009. -304 c.

68. Глазьев, С. Ю. Новый технологический уклад в современной мировой экономике / С. Ю. Глазьев // Международная экономика. - 2010. - № 5. - С. 5-27.

69. Иншаков, О. В. Индустрия как форма утверждения, распространения и господства хозяйственного уклада в экономике / О. В. Иншаков, А. В. Фесюн // Вестник Волгоградского гос. ун-та. Сер. 3: Экономика, экология. - 2014. - № 2. - С. 44-53. 
70. Фролов, Д. Кризис наноиндустрии и ее будущее / Д. Фролов, И. Полынцев // Экономист. - 2016. - № 2.

71. Сухарев, О. С. Индустриальная политика и развитие промышленных систем: Эволюция, институты и управление / О. С. Сухарев, Е. Н. Стрижакова. - М.: ЛЕНАНД, 2015. - $160 \mathrm{c}$.

72. Наумович, О. А. Смена технологических укладов как социально-экономический феномен / О. А. Наумович // Экономическая наука сегодня : сб. науч. ст. / БНТУ. 2016. - Вып. 4. - С. 34-38.

\section{REFERENCES}

1. Bodrijyar, Zh. Prozrachnost' zla / Zh. Bodrijyar ; Per. s fr. L. Lyubarskoj, E. Markovskoj. . - 5-e izd. - M.: «Dobrosvet», «Izdatel'stvo "KDU"», 2014. - $260 \mathrm{~s}$.

2. Ehko, Um. Otkroveniya molodogo romanista / Um. Ehko. - M.: AST; Corpus. 2013. $-320 \mathrm{c}$.

3. Struve, P. B. Pervichnost' i svoeobrazie obmena i problema «ravnovesiya». Otvet A. D. Bilimovichu / P. B. Struve // Ehkonomicheskij Vestnik. - 1924. - Kn. 3 (1) - S. 33-50

4. Sovremennye global'nye transformacii i problema istoricheskogo samo-opredeleniya vostochnoslavyanskih narodov: monogr. / Ch. S. Kirvel' [i dr.]; pod nauch. red. Ch. S. Kirvelya. 2-e izd., pererab. i dop. - Grodno: GrGU, 2009. - 547 s.

5. Kejns, Dzh. Obshchaya teoriya zanyatosti, procenta i deneg [Ehlektronnyj resurs] / Dzh. Kejns // Uchebniki, monografii po sociologii. - Rezhim dostupa: http://socioline.ru/files/ 5/316/keyns.pdf. - Data dostupa: 23.08.2016.

6. Solodovnikov, S. Yu. Kul't kargo, ili Novyj ob"ekt ehkonomicheskoj nauki / S. Yu. Solodovnikov // Belorusskaya dumka. - 2016. - № 1. - S. 56-62.

7. Borisov, B. Golodomor po-amerikanski / B. Borisov [EHlektronnyj resurs] // Oko planety. Novosti, analitika, informaciya. - Rezhim dostupa: http://oko-planet.su/first/4702-boris-borisov-golodomor-po-amerikanski.html. - Data dostupa: 14.09.2016.

8. Chun'kov, Yu. I. Vzaimodejstvie ob"ektivnogo i sub"ektivnogo v sociali-sticheskoj ehkonomike : (Politehkonomicheskij aspekt issledovaniya) / Yu. I. Chun'kov. - Tomsk: Izd-vo Tomskogo un-ta, 1984. - 193 s.

9. Ansar, P. Sovremennaya sociologiya / P. Ansar // Sociologicheskie issledova-niya. 1996. - № 1. - S. 134-150.

10. Radaev, V. V. Sociologiya rynkov: k formirovaniyu novogo napravleniya / V. V. Radaev. - M.: GU VSHEH, 2003. - 328 s.

11. Ippolitov, L. Zarozhdenie institucionalistskoj ehkonomicheskoj teorii v Rossii (ob odnoj metodologicheskoj diskussii 1920-h godov / L. Ippolitov // Vest-nik Instituta ehkonomiki Rossijskoj akademii nauk. - 2008. - № 4. - S. 43-57.

12. Bulgakov, S. N. Filosofiya hozyajstva / S. N. Bulgakov / Otv. red. O. Platonov. M.: Institut russkoj civilizacii, 2009. - $464 \mathrm{~s}$.

13. Tugan-Baranovskij, M. I. Social'naya teoriya raspredeleniya / M. I. Tugan-Baranovskij // Izvestiya S.-Peterburgskogo politicheskogo instituta, otdel nauk ehko-nomicheskih $\mathrm{i}$ istoricheskih. $-1913 .-$ T. 20. - S. 1-20

14. Struve, P. Hozyajstvo i cena. Kriticheskie issledovaniya po teorii i isto-rii hozyajstvennoj zhizni. Ch. 1 / P. Struve. - SPb.; M., 1913. - 358 s.

15. Mirovaya ehkonomicheskaya mysl'. Skvoz' prizmu vekov. V 5 t. - T. III. Ehpoha social'nyh perelomov / Otv. red. A. G. Hudokormov. - M., 2005. - 893 s.

16. Struve, P. B. Nauchnaya kartina ehkonomicheskogo mira i ponyatie «ravnovesiya» / P. B. Struve // EHkonomicheskij Vestnik. - 1923. - Kn. 1. - S. 5-26. 
17. Radaev, V. V. K obosnovaniyu modeli povedeniya cheloveka v sociologii (os-novy «ehkonomicheskogo imperializma») / V. V. Radaev // Sociologicheskie chteniya. Vyp. 2. - M.: Institut «Otkrytoe obshchestvo»: Institut sociologii RAN, 1997. - S. 177-189.

18. Radaev, V. V. Rynok kak ob"ekt sociologicheskogo issledovaniya / V. V. Radaev // Sociologicheskie issledovaniya. - 1999. - № 3. - S. 28-37.

19. Becker, G. Nobel Lecture: The Economic Way of Looking at Behavior / G. Becker // Journal of Political Economy. - 1993. - Vol. 101. - P. 385-409.

20. Bekker, G. Vybor partnera na brachnyh rynkah / G. Bekker // THESIS. - 1994. Vyp. 6. - S. 12-36.

21. Shul'c, T. Cennost' detej / T. SHul'c // THESIS. - 1994. - Vyp. 6. - S. 37-49.

22. B'yukenen, Dzh. M. Sochineniya / Dzh. M. B'yukenen. - T. 1. - M.: Taurus-Al'fa, 1997. - $556 \mathrm{~s}$.

23. Block, F. The Role of the State in the Economy / N. Smelser, R. Swedberg (eds.). // The Handbook of Economic Sociology. - Princeton: Princeton University Press, 1994. P. 206-232.

24. Evans, P. B. Embedded Autonomy / P. B. Evans. - Berkeley: University of California Press, 1995.

25. Frye, T. The Invisible Hand and the Grabbing Hand / T. Frye, A. Schleifer // American Economic Review. Papers and Proceedings. - 1997. - Vol. 87. - № 2. - P. 354-358.

26. Shleifer, A. The Grabbing Hand: Government Pathologies and Their Cures / A. Schleifer, R. Vishny. - Cambridge: Harvard University Press, 1998. - 278 p.

27. Bell, D. The Coming of Post-Industrial Society: A Venture in Social Forecasting / D. Bell. - New York: Basic Books, 1973. - 507 p.

28. Veredyuk, O. V. Determinanty zanyatosti v koncepcii postindustrial'nogo obshchestva / O. V. Veredyuk // Vestnik SPbGU. Ser 5. - 2010. - Vyp. 4. - S. 35-41.

29. Machlup, F. The Production and Distribution of Knowledge in the United States / F. Machlup. - Princeton University Press, 1962. - 523 p.

30. The Knowledge Society / Ed. by G. Bohme \& N. Stehr. D. - Reidel Publishing Company, Holland, 1984. - 209 p.

31. Brzezinski, Z. Between Two Ages: America's Role in the Technetronic Era / Z. Brzezinski. - New York: The Viking Press, 1970. - 355 p.

32. Castells, M. The Information Age: Economy, Society and Culture / M. Castells // The Rise of the Network Society. - London and Oxford: Blackwell Publisher, 1996. - Vol. I. P. 151-200.

33. Roszak, T. Where the Wasteland Ends: Politics and Transcendence in Postindustrial Society / T. Roszak. - Garden City; New York: Doubleday \& Company, 1972. - 492 p.

34. Inozemcev, V. L. Za predelami ehkonomicheskogo obshchestva / V. L. Inozemcev. - M.: Academia. - Nauka, 1998. - $640 \mathrm{~s}$

35. Castells, M. The Rise of the Network Society: 2nd ed. / M. Castells. - Wiley-Blackwell, 2010. $-597 \mathrm{p}$.

36. Toffler, A. Creating a New Civilization. The Politics of the Third Wave / A. Toffler, H. Toffler. - Turner Publishing, Atlanta, 1993. [Electronic resource]. - Mode of access : http://www.archipelag.ru/autors/toffler. - Date of access : 17.10.2010.

37. Solodovnikov, S. Yu. Social'no-ehkonomicheskie faktory, opredelyayushchie izmenenie sistemy trudovoj motivacii v novyh social'no-ehkonomicheskih i tekhnolo-gicheskih usloviyah v Belarusi / S. Yu. Solodovnikov // EHkonomicheskaya nauka segodnya : sb. nauch. st. / BNTU. - Minsk, 2017. - Vyp. 5. - S. 296-308. 
38. Solodovnikov, S. Yu. Social'nyj kapital kak ehkonomicheskij resurs / S. Yu. Solodovnikov // Vestnik Polockogo gosudarstvennogo universiteta. Seriya D, Ehkonomicheskie i yuridicheskie nauki. - 2015. - № 5. - S. 2-9.

39. Solodovnikov, S. Yu. Civilizaciya, kul'tura, institucional'nye matricy i ehkonomicheskaya sistema obshchestva: fenomenologicheskaya priroda, vzaimoobuslovlen-nost', social'nyj genezis / S. Yu. Solodovnikov // Voprosy servisa i ehkonomiki. - 2012. - № 4. - S. 5-22.

40. Deutschlands Zukunft als Produktionsstandort sichern. Umsetzungsempfehlungen für das Zukunftsprojekt Industrie 4.0. Abschlussbericht des Arbeitskreises Industrie 4.0 [Elektronische Quelle] / Promotorengruppe Kommunikation der Forschungsunion Wirtschaft Wissenschaft // Bundesministerium für Bildung und Forschung. - 116 s. - Zugriffsmodus: https://www.bmbf.de/files/Umsetzungsempfehlungen_Industrie4_0.pdf. - Zugriffsdatum: 08.08.2018.

41. Meleshko, Yu. V. Sistemoobrazuyushchie principy razvitiya uslug promysh-lennogo haraktera / Yu. V. Meleshko // Ustojchivoe razvitie ehkonomiki: sostoyanie, pro-blemy, perspektivy: sbornik trudov XI mezhdunarodnoj nauchno-prakticheskoj konfe-rencii. - 2017. S. 84-86.

42. Meleshko, Yu. V. Ocenka ehffektivnosti razvitiya uslug promyshlennogo ha-raktera $\mathrm{v}$ kontekste modernizacii nacional'nogo promyshlennogo kompleksa / Yu. V. Meleshko // Vestnik Komi respublikanskoj akademii gosudarstvennoj sluzhby i upravleniya. Seriya: Teoriya i praktika upravleniya. - 2017. - № 18 (23). - S. 39-47.

43. Meleshko, Yu. V. Ehvolyuciya uslug promyshlennogo haraktera v Respublike Belarus' v 1995-2015 gg. / Yu. V. Meleshko // Ehkonomicheskaya nauka segodnya : sb. nauch. st. / BNTU. - Minsk, 2017. - № 5. - S. 127-144.

44. Meleshko, Yu. V. Znachenie uslug promyshlennogo haraktera v povyshenii konkurentosposobnosti promyshlennyh predpriyatij (v kontekste chetvertoj pro-myshlennoj revolyucii) / Yu. V. Meleshko // Ehkonomicheskaya nauka segodnya : sb. nauch. st. / BNTU. - Minsk, 2017. - № 6. - S. 64-78.

45. Sergievich, T. V. Trud v neoindustrial'nom obshchestve / T. V. Sergievich // Nauchno-obrazovatel'nyj centr «Tekhnologii tovarovedcheskoj, tamozhennoj i krimi-nalisticheskoj ehkspertizy» Sbornik nauchnyh rabot № 6. Pod redakciej G. D. Drozdova. - SPb.: Izdvo SPbGEHU, 2015. - S. 50-55.

46. Solodovnikov, S. Yu. Tendencii i perspektivy razvitiya zanyatosti i so-zdaniya social'no-nauchnogo soobshchestva $\mathrm{v}$ usloviyah modernizacii tranzitivnoj ehko-nomiki: na primere Respubliki Belarus' / S. Yu. Solodovnikov // Vestnik Polockogo gosudarstvennogo universiteta. Seriya D, Ehkonomicheskie i yuridicheskie nauki. - 2015. - № 6. - S. 2-9.

47. Meleshko, Yu. V. Metodicheskoe obespechenie sovershenstvovaniya ehkonomiche-skogo mekhanizma okazaniya uslug promyshlennogo haraktera / Yu. V. Meleshko // Vestnik Polockogo gosudarstvennogo universiteta. Seriya D: Ehkonomicheskie i yuridicheskie nauki. - Minsk, 2016. - № 14. - S. 51-60.

48. Meleshko, Yu. V. Osnovnye formy sotrudnichestva predpriyatij real'nogo sektora ehkonomiki Respubliki Belarus' i Rossijskoj Federacii v sfere proizvod-stva kosmicheskoj tekhniki / Yu. V. Meleshko // Pravo. Ehkonomika. Psihologiya. - 2018. - № 1 (9). - S. 37-42.

49. Solodovnikov, S. Yu. Gnoseologicheskie trudnosti pri izuchenii klassov v postindustrial'nom obshchestve / S. Yu. Solodovnikov // Sociologicheskij al'manah. - $2012-$ № 3. - S. 74-91.

50. Solodovnikov, S. Yu. Teoretiko-metodologicheskie osnovy issledovaniya vzaimosvyazi teorii trudovoj motivacii i dinamiki trudovyh otnoshenij / S. Yu. Solodovnikov, T. V. Sergievich // Vestnik Polockogo gosudarstvennogo universiteta. Seriya D, Ehkonomicheskie i yuridicheskie nauki. - 2016. - № 5. - S. 12-16. 
51. Bodrijyar, Zh. K kritike politicheskoj ehkonomii znaka / Zh. Bodrijyar / per. s fr. D. Kralechkin. - M. : Akademicheskij Proekt, 2007. - 335 s.

52. Veblen, Th. The Theory of the Leisure Class / Th. Veblen. - 1899, fr. per.: La Theorie de la classe de loisir; Paris, Gallimard, 1969.

53. Sergievich, T. V. Moda kak ob"ekt ehkonomicheskogo issledovaniya / T. V. Sergievich // Biznes. Innovacii. Ehkonomika : sb. nauchn. st. / Institut biznesa i menedzhmenta tekhnologij BGU; redkol.: V. V. Apanasovich (predsedatel'). - Minsk: Pechatnyj Dom «Vishnevka», 2017. - Vyp. 1. - S. 170-179.

54. Sergievich, T. V. Sovershenstvovanie organizacionno-ehkonomicheskogo mehanizma proizvodstva tovarov intensivnogo obnovleniya : avtoref. dis. ... kand. ehkon. nauk : 08.00.05 / T. V. Sergievich ; BGU. - Minsk, 2018. - 30 s.

55. Solodovnikov, S. Yu. Fenomenologicheskaya priroda vzaimoobuslovlennosti ehkonomicheskoj konkurentosposobnosti i social'nogo kapitala Belarusi i Ukrainy / S. Yu. Solodovnikov // Ehkonomicheskaya nauka segodnya : sb. nauch. st. / BNTU. - Minsk, 2015 - Vyp. 3. S. 23-34.

56. Solodovnikova, T. V. Instrumenty podmeny osnovanij v sovremennom ehkonomicheskom diskurse / T. V. Solodovnikova // Pravo. Ehkonomika. Psihologiya. - 2018. № 1 (9). - S. 43-48.

57. Solodovnikova, T. V. Lozhnaya argumentaciya kak instrument ehkonomicheskogo diskursa / T. V. Solodovnikova // EHkonomicheskie issledovaniya i razrabotki: nauchno-issledovatel'skij zhurnal. - Nizhnij Novgorod: NOO «Professional'naya nauka». - 2017. - № 2. S. $125-143$.

58. Solodovnikov, S. Yu. Klassy i klassovaya bor'ba v postindustrial'nom obshchestve: metodologicheskie osnovy politiko-ehkonomicheskogo issledovaniya / S. Yu. Solodovnikov. Minsk : BNTU, 2014. - $378 \mathrm{~s}$.

59. Sazhina, M. A. Priroda sovremennyh finansov / M. A. Sazhina // EHkonomi-cheskie nauki. - 2014. - № 9. - S. 25-33.

60. Gubanov, S. Ob ehkonomicheskoj modeli i dolgosrochnoj strategii novoj in-dustrializacii Rossii / S. Gubanov // Ehkonomist. - 2016. - № 2 - S. 3-10.

61. Frolov, D. Krizis nanoindustrii i ee budushchee / D. Frolov, I. Polyncev // Ehkonomist. - 2017. - № 5 - S. 27-37.

62. The National Nanotechnology Initiative Supplement to the President's 2017 Budget // National Science and Technology Council. - 2016. - 104 p.

63. Arskij, Yu. M. Ot redakcionnoj kollegii / Yu. M. Arskij // Industriya nanosistem I nanomaterialov. - 2007. - № 1.

64. Hullman, A. Who is winning the global nanorace? / A. Hullman // Nature Nanotechnology. -2006 . - № 1. - P. 81-83.

65. Nanomanufacturing: Emergence and Implications for U. S. Competitiveness, the Environment, and Human Health. Report to Congressional Requesters // United States Government Accounability Office. - 2014. - P. 22.

66. Kastel's, M. Informacionnaya ehpoha: ehkonomika, obshchestvo i kul'tura / M. Kastel's. - M.: GU VSHEH. - 2000. - 608 s.

67. Nanotekhnologii kak klyuchevoj faktor novogo tekhnologicheskogo uklada v ehkonomike» / S. Yu. Glaz'ev [i dr] ; pod red. S. Yu. Glaz'eva, V. V. Haritonova. - M.: Trovant, 2009. - $304 \mathrm{~s}$.

68. Glaz'ev, S. Yu. Novyj tekhnologicheskij uklad v sovremennoj mirovoj ehkonomike / S. Yu. Glaz'ev // Mezhdunarodnaya ehkonomika. - 2010. - № 5. - S. 5-27. 
69. Inshakov, O. V. Industriya kak forma utverzhdeniya, rasprostraneniya i gos-podstva hozyajstvennogo uklada v ehkonomike / O. V. Inshakov, A. V. Fesyun // Vestnik Volgogradskogo gos. un-ta. Ser. 3: Ehkonomika, ehkologiya. - 2014. - № 2. - S. 44-53.

70. Frolov, D. Krizis nanoindustrii i ee budushchee / D. Frolov, I. Polyncev // Ehkonomist. - 2016. - № 2.

71. Suharev, O. S. Industrial'naya politika i razvitie promyshlennyh sistem: Ehvolyuciya, instituty i upravlenie / O. S. Suharev, E. N. Strizhakova. - M.: LENAND, 2015. - 160 s.

72. Naumovich, O. A. Smena tekhnologicheskih ukladov kak social'no-ehkono-micheskij fenomen / O. A. Naumovich // Ehkonomicheskaya nauka segodnya : sb. nauch. st. / BNTU. - 2016. - Vyp. № 4. - S. 34-38.

Статья поступила в редакиию 24 августа 2018 года. 